\title{
Multinational Firms, FDI Flows and Imperfect Capital Markets
}

\section{Citation}

Antras, Pol, Mihir A. Desai, and C. Fritz Foley. 2009. Multinational firms, FDI flows and imperfect capital markets. Quarterly Journal of Economics 124(3): 1171-1219.

\section{Published Version}

doi:10.1162/qjec.2009.124.3.1171

\section{Permanent link}

http://nrs.harvard.edu/urn-3:HUL.InstRepos:3199065

\section{Terms of Use}

This article was downloaded from Harvard University's DASH repository, and is made available under the terms and conditions applicable to Open Access Policy Articles, as set forth at http:// nrs.harvard.edu/urn-3:HUL.InstRepos:dash.current.terms-of-use\#OAP

\section{Share Your Story}

The Harvard community has made this article openly available.

Please share how this access benefits you. Submit a story.

Accessibility 


\title{
Multinational Firms, FDI Flows and Imperfect Capital Markets
}

\author{
Pol Antràs, Mihir A. Desai, and C. Fritz Foley*
}

June 2008

\begin{abstract}
This paper examines how costly financial contracting and weak investor protection influence the cross-border operational, financing and investment decisions of firms. We develop a model in which product developers can play a useful role in monitoring the deployment of their technology abroad. The analysis demonstrates that when firms want to exploit technologies abroad, multinational firm (MNC) activity and foreign direct investment (FDI) flows arise endogenously when monitoring is nonverifiable and financial frictions exist. The mechanism generating MNC activity is not the risk of technological expropriation by local partners but the demands of external funders who require MNC participation to ensure value maximization by local entrepreneurs. The model demonstrates that weak investor protections limit the scale of multinational firm activity, increase the reliance on FDI flows and alter the decision to deploy technology through FDI as opposed to arm's length technology transfers. Several distinctive predictions for the impact of weak investor protection on MNC activity and FDI flows are tested and confirmed using firm-level data.
\end{abstract}

${ }^{*}$ Harvard University and NBER; Harvard Business School and NBER; Harvard Business School and NBER, respectively. The statistical analysis of firm-level data on U.S. multinational companies was conducted at the International Investment Division, Bureau of Economic Analysis, U.S. Department of Commerce under arrangements that maintain legal confidentiality requirements. The views expressed are those of the authors and do not reflect official positions of the U.S. Department of Commerce. The authors thank Robert Barro, four anonymous referees, Gita Gopinath, James Markusen, Aleh Tsyvinski, Bill Zeile and seminar participants at Boston University, Brown University, Hitotsubashi University, MIT, the NBER ITI program meeting, the New York Fed, Oxford, UC Berkeley, UC Boulder, Universidad de Vigo, Universitat Pompeu Fabra, the University of Michigan, and the World Bank for helpful suggestions. Davin Chor provided excellent research assistance. 


\section{Introduction}

Firms globalizing their operations and the associated capital flows have become major features of the world economy. These cross-border activities and capital flows span institutional settings with varying investor protections and levels of capital market development. While the importance of institutional heterogeneity in dictating economic outcomes has been emphasized, existing analyses typically ignore the global firms and the capital flows that are now commonplace. Investigating how global firms make operational and financing decisions in a world of heterogenous institutions promises to provide a novel perspective on observed patterns of flows and firm activity.

This paper develops and tests a model of the operational and financial decisions of firms as they exploit their technologies in countries with differing levels of investor protections. The model demonstrates that multinational firm (MNC) activity and foreign direct investment (FDI) arise endogenously in settings characterized by financial frictions. The model generates several predictions regarding how investor protections influence the use of arm's length technology transfers, the degree to which multinational firm activity is financed by capital flows, the extent to which multinationals take ownership in foreign projects, and the scale of multinational operations. These predictions are tested using firm-level data on U.S. multinational firms.

The model considers the problem of a firm that has developed a proprietary technology and is seeking to deploy this technology abroad with the help of a local entrepreneur. A variety of alternative arrangements, including an arm's length technology transfer or directly owning and financing the entity that uses it, are considered. External investors are a potential source of funding, but they are concerned with managerial misbehavior, particularly in settings where investor protections are weak. The central premise of the model is that developers of technologies are particularly useful monitors for ensuring that local entrepreneurs are pursuing value maximization. The concerns of external funders regarding managerial misbehavior lead to optimal contracts in which the developer of the technology is required to hold an ownership claim in the foreign project and, in certain cases, this developer is also required to provide financial capital to the local entrepreneur. As such, multinational firms and FDI flows arise endogenously in response to concerns over managerial misbehavior and weak investor protections. ${ }^{1}$ Extending the model to

\footnotetext{
${ }^{1}$ The experience of Disney in Japan, as documented in Misawa (2005), provides one example of the mechanism that drives the behavior of external investors. In 1997, Disney was evaluating how to structure a new opportunity with a local partner in Japan. Japanese banks expressed a strong preference for equity participation by Disney over a licensing agreement in order to ensure that Disney had strong incentives to monitor the project and ensure value maximization. The concerns of these lenders and the intuition that Disney would have a unique ability to monitor local partners are reflective of the central ideas of
} 
allow for a similar form of monitoring by external investors does not vitiate the primary results. We also show that while simple revenue-sharing agreements may also provide incentives for technology developers to monitor, this type of contract is generally not optimal.

The characterization of multinational firms as developers of technologies has long been central to models explaining multinational firm activity. In contrast to those models that emphasize the risk of technology expropriation, the model in this paper emphasizes financial frictions, a cruder form of managerial opportunism and the role of external funders. As such, while technology is central to these other models and the model in this paper, the mechanism generating multinational firm activity is entirely distinct. Our emphasis on monitoring builds on the theory presented in Holmstrom and Tirole (1997) which captures how monitoring is critical to understanding financial intermediation.

Our model delivers several novel predictions about the nature of FDI and patterns of multinational firm activity. First, the model predicts that arm's length technology transfers will be more common, relative to the deployment of that technology through affiliate activity, in countries where investor protections are stronger. Second, the share of activity abroad financed by capital flows from the multinational parent will be decreasing in the quality of investor protections in host economies. Third, ownership shares by multinational parents will also be decreasing in the quality of investor protections in host economies. These predictions reflect the fact that monitoring by the developer of the technology is more critical in settings where investor protections are weaker. The model also predicts that the scale of activity based on multinational technologies in host countries will be an increasing function of the quality of the institutional environment. Better investor protections reduce the need for monitoring and therefore allow for a larger scale of activity.

We test these predictions using the most comprehensive available data on the activities of U.S. multinational firms and on arm's length technology transfers by U.S. firms. These data provide details on the world wide operations of U.S. firms, including measures of parental ownership, financing and operational decisions, and information on royalty payments and licensing fees received by U.S. firms from unaffiliated foreign persons. The data enable the use of parent-year fixed effects that implicitly control for a variety of unobserved attributes.

The analysis indicates that the likelihood of using arm's length technology transfer to serve a foreign market increases with measures of investor protections, as suggested by the model. The predictions on parent financing and ownership decisions are also the model. 
confirmed to be a function of the quality of investor protections and the depth of capital markets. The model also suggests that these effects should be most pronounced for technologically advanced firms because these firms are most likely to be able to provide valuable monitoring services. The empirical evidence indicates a differential effect for such firms.

Settings where ownership restrictions are liberalized provide an opportunity to test the final prediction of the model. The model implies that ownership liberalizations should have a particularly large effect on multinational affiliate activity in countries with weak investor protections. Our empirical analysis confirms that affiliate activity increases by larger amounts after liberalizations in countries with weaker investor protections.

This paper extends the large and growing literature on the effects of investor protections and capital market development on economic outcomes to an open economy setting where firms make operational and financial decisions across borders. La Porta, Lopez-deSilanes, Shleifer and Vishny $(1997,1998)$ relate investor protections to the concentration of ownership and the depth of capital markets. A large literature, including King and Levine (1993), Levine and Zervos (1998), Rajan and Zingales (1998), Wurgler (2000), and Acemoglu, Johnson and Mitton (2005), has shown that financial market conditions influence firm investment behavior, economic growth and industrial structure.

By exclusively emphasizing firms with local investment and financing, this literature has neglected how cross-border, intrafirm activity responds to institutional variations. The open economy dimensions of institutional variations have been explored, but overwhelmingly in the context of arm's-length cross-border lending as in Gertler and Rogoff (1990), Boyd and Smith (1997) and Shleifer and Wolfenzon (2002). ${ }^{2}$ In related work, Albuquerque (2003) shows that the differential alienability of FDI and portfolio inflows can allow the risk of expropriation to alter the composition of capital inflows. In contrast to this work, we derive the existence of multinational firms and FDI flows in response to the possibility of opportunism by private actors. Accordingly, our empirical work employs firm-level data that allows us to analyze both patterns of firm activity and financial flows rather than the division of aggregate capital flows between FDI and portfolio flows. In short, we show that weak financial institutions decrease the scale of multinational firm activity but simultaneously increase the reliance on capital flows from the parent. As such, observed patterns of capital flows reflect these two distinct and contradictory effects. The

\footnotetext{
${ }^{2}$ Gertler and Rogoff (1990) show how arms-length lending to entrepreneurs in poor countries is limited by their inability to pledge large amounts of their own wealth. This insight is embedded into a multinational firm's production decisions in the model presented here. Our setup also relates to Shleifer and Wolfenzon (2002), who study the interplay between investor protection and equity markets. In contrast, Kraay et al. (2005) emphasize the role of sovereign risk in shaping the structure of world capital flows.
} 
empirical investigations of micro-data provided in the paper indicate that both effects are operative. $^{3}$

By jointly considering the determinants of $\mathrm{MNC}$ activities and the flows of capital that support these activities, the paper also links two literatures - the international trade literature on multinationals and the macroeconomic literature on capital flows. Industrial organization and international trade scholars characterize multinationals as having proprietary assets and emphasize the role of market imperfections, such as transport costs and market power, in determining patterns of multinational activity. Recent work on multinational firms investigates "horizontal" or "vertical" motivations ${ }^{4}$ for foreign direct investment and explores why alternative productive arrangements, such as whole ownership of foreign affiliates, joint ventures, exports or arm's length contracts, are employed. ${ }^{5}$

Such analyses of multinational firm activity typically do not consider associated capital flows. ${ }^{6}$ Research on capital flows typically abstracts from firm activity and has focused on the paradox posed by Lucas (1990) of limited capital flows from rich to poor countries in the face of large presumed rate of return differentials. While Lucas (1990) emphasizes human-capital externalities to help explain this paradox, Reinhart and Rogoff (2004)

\footnotetext{
${ }^{3}$ It should be emphasized that our model abstracts from any portfolio decision by consumers and instead focuses on the financing decisions of firms. Bertaut, Griever and Tryon (2006) analyze U.S. ownership of foreign securities and conclude that non-financial institutions are a fairly small fraction (less than 10\%) of overall foreign portfolio investment, and this is when including all securities such as fixed income investments. As such, our model (unlike the one in Albuquerque (2003)) may not be particularly well suited to interpret cross-country patterns in the composition of capital flows.

${ }^{4}$ The horizontal FDI view represents FDI as the replication of capacity in multiple locations in response to factors such as trade costs, as in Markusen (1984), Brainard (1997), Markusen and Venables (2000), and Helpman, Melitz and Yeaple (2004). The vertical FDI view represents FDI as the geographic distribution of production globally in response to the opportunities afforded by different markets, as in Helpman (1984) and Yeaple (2003). Caves (1996) and Markusen (2002) provide particularly useful overviews of this literature.

${ }^{5}$ Antràs (2003, 2005), Antràs and Helpman (2004), Desai, Foley and Hines (2004), Ethier and Markusen (1996), Feenstra and Hanson (2005), and Grossman and Helpman (2004) analyze the determinants of alternative foreign production arrangements.

${ }^{6}$ Several studies linking levels of MNC activity and FDI flows are worth noting. First, high frequency changes in FDI capital flows have been linked to relative wealth levels through real exchange rate movements (as in Froot and Stein (1991) and Blonigen (1997)), broader measures of stock market wealth (as in Klein and Rosengren (1994) and Baker, Foley and Wurgler (forthcoming)) and to credit market conditions (as in Klein, Peek and Rosengren (2002)). Second, multinational firms have also been shown to opportunistically employ internal capital markets in weak institutional environments (as in Desai, Foley and Hines (2004b)) and during currency crises (as in Aguiar and Gopinath (2005) and Desai, Foley and Forbes (forthcoming)). These papers emphasize how heterogeneity in access to capital can interact with multinational firm production decisions. Marin and Schnitzer (2004) also study the financing decisions of multinational firms in a model that stresses managerial incentives. Their model however takes the existence of multinational firms as given and considers an incomplete-contracting setup in contrast to our complete-contracting setup. The predictions from their model are quite distinct (and typically contradictory) to the ones we develop here and show to be supported by U.S. data.
} 
review subsequent research on aggregate capital flows and conclude that credit market conditions and political risk play significant roles. By examining firm behavior in a setting with variation in investor protections, this paper attempts to unify an investigation of multinational firm activity and FDI flows.

The rest of the paper is organized as follows. Section 2 lays out the model and generates several predictions related to the model. Section 3 provides details on the data employed in the analysis. Section 4 presents the results of the empirical analysis and Section 5 concludes.

\section{Theoretical Framework}

In this section, we develop a model of financing that builds on and extends the work of Holmstrom and Tirole (1997). ${ }^{7}$ We illustrate how the model generates both multinational activity as well as foreign direct investment flows. Finally, we explore some firm-level empirical predictions that emerge from the model and that we take to the data in later sections.

\subsection{A Model of Financial Contracting}

\section{Environment}

We consider the problem of an agent - an inventor - who is endowed with an amount $W$ of financial wealth and the technology or knowledge to produce a differentiated good. Consumers in two countries, Home and Foreign, derive utility from consuming this differentiated good. (Appendix A.1 develops a multi-country version of the model.) The good, however, is prohibitively costly to trade and thus servicing a particular market requires setting up a production facility in that country. The inventor is located at Home and cannot fully control production in Foreign. Servicing that market thus requires contracting with a foreign agent - an entrepreneur - to manage production there. We assume that entrepreneurs are endowed with no financial wealth and their outside option is normalized to 0 . There also exists a continuum of infinitessimal external investors in Foreign that have access to a technology that gives them a gross rate of return equal to 1 on their wealth. All parties are risk neutral and are protected by limited liability. There

\footnotetext{
${ }^{7}$ Our model generalizes the setup in Holmstrom and Tirole (1997) by allowing for diminishing returns to investment and for variable monitoring levels. The scope of the two papers is also very distinct: Holmstrom and Tirole (1997) study the monitoring role of banks in a closed-economy model, while our focus is on multinational firms.
} 
are three periods, a date 0 contracting stage, a date 1 investment stage, and a date 2 production/consumption stage.

\section{Consumer Preferences and Technology}

In the main text, we focus on describing production and financing decisions in the Foreign market. For that purpose, we assume that preferences and technology at Home are such that at date 2 the inventor obtains a constant gross return $\beta>1$ for each unit of wealth he invests in production at Home at date 1. We refer to this gross return as the inventor's shadow value of cash. Our assumption $\beta>1$ implies that the opportunity cost of funds is lower for external investors than for the inventor. In Appendix A.1, this higher-than-one value of $\beta$ is endogenously derived in a multi-country version of the model where consumer preferences, technology and financial contracting in all countries are fully specified. It is important to note that the provision that $\beta>1$ does not imply that the effective cost of capital provided by external investors is always lower than the effective cost of capital provided by the inventor, as informational frictions may drive a wedge between returns earned and the costs borne by the relevant parties.

We assume that Foreign preferences are such that cash flows or profits obtained from the sale of the differentiated good in Foreign can be expressed as a strictly increasing and concave function of the quantity produced, i.e., $R(q)$, with $R^{\prime}(q)>0$ and $R^{\prime \prime}(q) \leq 0$. We also assume the standard conditions $R(0)=0, \lim _{q \rightarrow 0} R^{\prime}(q)=+\infty$, and $\lim _{q \rightarrow \infty} R^{\prime}(q)=0$. These properties of $R(q)$ can be derived from preferences featuring a constant (and higher-than-one) elasticity of substitution across a continuum of differentiated goods produced by different firms. In such case, the elasticity of $R(q)$ with respect to $q$ is constant and given by a parameter $\alpha \in(0,1)$.

Foreign production is managed by the foreign entrepreneur, who at date 1 can privately choose to behave and enjoy no private benefits, or misbehave and take private benefits. When the manager behaves, the project performs with probability $p_{H}$, in the sense that when an amount $x$ is invested at date 1 , project cash flows at date 2 are equal to $R(x)$ with probability $p_{H}$ and 0 otherwise. ${ }^{8}$ When the manager misbehaves, the project performs with a lower probability $p_{L}<p_{H}$ and expected cash flows are $p_{L} R(x)$. We assume that the private benefit a manager obtains from misbehaving is increasing in the size of the project, and for simplicity, we specify it as being proportional to the return of the project, i.e., $B R(x)$. In section 2.3 , we discuss how similar results obtain if private benefits are

\footnotetext{
${ }^{8}$ This assumes that, when the project succeeds, each unit invested results in a unit of output $(q=x)$, while when the project fails, output is zero $(q=0)$. We shall relax the latter assumption in section 2.3 below.
} 
proportional to the level of investment $x$.

Managerial misbehavior and the associated private benefits can be manifest by choosing to implement the project in a way that generates perquisites for the manager or his associates, in a way that requires less effort, or in a way that is more fun or glamorous. As described below, we will relate the ability to engage in such private benefits to the level of investor protections in Foreign as well as to the extent to which the entrepreneur is monitored. The idea is that countries with better investor protections tend to enforce laws that limit the ability of managers to divert funds from the firm or to enjoy private benefits or perquisites. This interpretation parallels the logic in Tirole (2006, p. 359).

When investor protections are not perfectly secure, monitoring by third agents is helpful in reducing the extent to which managers are able to divert funds or enjoy private benefits. Following Holmstrom and Tirole (1997), we introduce a monitoring technology that reduces the private benefit of the foreign entrepreneur when he misbehaves. It is reasonable to assume that the inventor can play a particularly useful role in monitoring the behavior of the foreign entrepreneur because the inventor is particularly well informed about how to manage the production of output using its technology. Intuitively, the developer of a technology is in a privileged position to determine if project failure is associated with managerial actions or bad luck. ${ }^{9}$ We capture this in a stark way by assuming that no other agent in the economy can productively monitor the foreign entrepreneur, though we will discuss a more general setup in section 2.3 below. We assume that monitoring costs are proportional to the return of the project and when the inventor incurs an effort cost $C R(x)$ in monitoring at date 1, the private benefit for the local entrepreneur is multiplied by a factor $\delta(C)$, with $\delta^{\prime}(C)<0, \delta^{\prime \prime}(C)>0, \delta(0)=\bar{\delta}, \lim _{C \rightarrow \infty} \delta(C)=0$, $\lim _{C \rightarrow 0} \delta^{\prime}(C)=-\infty$, and $\lim _{C \rightarrow \infty} \delta^{\prime}(C)=0 .{ }^{10}$ This assumption reflects the idea that larger projects require effort to monitor. Section 2.3 considers the possibility that effort costs are proportional to investment levels and similar results follow.

As mentioned above, the scope of private benefits is related to the level of investor

\footnotetext{
${ }^{9}$ An alternative way to interpret monitoring is as follows. Suppose that the foreign entrepreneur can produce the good under a variety (a continuum, actually) of potential techniques indexed by $z \in[0, B]$. Technique 0 entails a probability of success equal to $p_{H}$ and a zero private benefit. All techniques with $z>0$ are associated with a probability of success equal to $p_{L}$ and a private benefit equal to $z$. Clearly, all techniques with $z \in(0, B)$ are dominated from the point of view of the foreign entrepreneur, who will thus effectively (privately) choose either $z=0$ or $z=B$, as assumed in the main text. Under this interpretation, we can think of monitoring as reducing the upper bound of $[0, B]$.

${ }^{10}$ These conditions are sufficient to ensure that the optimal contract is unique and satisfies the secondorder conditions.
} 
protection of the host country by an index $\gamma \in(0,1)$. In particular, we specify that

$$
B(C ; \gamma)=(1-\gamma) \delta(C)
$$

Note that this formulation implies that $\partial B(\cdot) / \partial \gamma<0, \partial B(\cdot) / \partial C<0$, and $\partial^{2} B(\cdot) / \partial C \partial \gamma=$ $-\delta^{\prime}(C)>0$. This formulation captures the intuition that the scope for private benefits is decreasing in both investor protection and monitoring, and that monitoring has a relatively larger effect on private benefits in countries with poor legal protection of investors. It also implies that parent monitoring substitutes for investor protection. The idea behind this assumption is that both parent monitoring and investor protections constrain managers and that parent monitoring is effective even in imperfect legal environments. This would be the case if, for example, parent monitoring during the production process prevented misbehavior from occurring, thus eliminating any need for legal action after improper behavior occurs.

\section{Contracting}

We consider optimal contracting between three sets of agents: the inventor, the foreign entrepreneur and foreign external investors. At date 0, the inventor and the foreign entrepreneur negotiate a contract that stipulates the terms under which the entrepreneur will exploit the technology developed by the inventor. This contract includes a (possibly negative) date- 0 transfer $F$ from the inventor to the entrepreneur, as well as the agents' date-2 payoffs contingent on the return of the project. ${ }^{11}$ When $F>0$, the date-0 payment represent the extent to which the inventor cofinances the project in the Foreign country. When $F<0$, this payment can be thought of as the price or upfront royalties paid for the use of the technology, which the inventor can invest in the Home market at date 1. The contract between the inventor and the entrepreneur also stipulates the date- 1 scale of investment $x$, while the managerial and monitoring efforts of the entrepreneur and inventor, respectively, are unverifiable and thus cannot be part of the contract.

Also at date 0 , the foreign entrepreneur and external investors sign a financial contract under which the entrepreneur borrows an amount $E$ from the external investors at date 0 in return for a date- 2 payment contingent on the return of the project.

We consider an optimal contract from the point of view of the inventor and allow the contract between the inventor and the entrepreneur to stipulate the terms of the financial contract between the entrepreneur and foreign external investors. We rule out "direct"

\footnotetext{
${ }^{11}$ For simplicity, we assume that the inventor's date-2 return in its Home market (which is not modelled in the main text) is not pleadgeable in Foreign.
} 
financial contracts between the inventor and foreign external investors. This is justified in the extension of the model developed in Appendix A.1, where the inventor's shadow value of cash $\beta$ is endogenized.

Given the payoff structure of our setup and our assumptions of risk neutrality and limited liability, it is straightforward to show that an optimal contract is such that all date- 2 payoffs can be expressed as shares of the return generated by the project. All agents obtain a payoff equal to zero when the project fails (that is when the return is zero), and a positive payoff when the project succeeds (in which case cash flows are positive). When an agent's share of the date-2 return is positive, this agent thus becomes an equity holder in the entrepreneur's production facility. ${ }^{12}$ We define $\phi_{I}$ and $\phi_{E}$ as the equity shares held by the inventor and external investors, respectively, with the remaining share $1-\phi_{I}-\phi_{E}$ accruing to the foreign entrepreneur. Notice that when $\phi_{I}$ is large enough, the entrepreneur's production facility becomes a subsidiary of the inventor's firm.

\subsection{Optimal Contract and Empirical Predictions}

We next characterize an optimal contract that induces the entrepreneur to behave and the inventor to monitor. This optimal contract is given by the tuple $\left\{\tilde{F}, \tilde{\phi}_{I}, \tilde{x}, \tilde{\phi}_{E}, \tilde{E}, \tilde{C}\right\}$ that solves the following program:

$$
\begin{array}{cl}
\max _{F, \phi_{I}, x, \phi_{E}, E, C} & \Pi_{I}=\phi_{I} p_{H} R(x)+(W-F) \beta-C R(x) \\
\text { s.t. } & x \leq E+F \\
& p_{H} \phi_{E} R(x) \geq E \\
& p_{H}\left(1-\phi_{E}-\phi_{I}\right) R(x) \geq 0 \\
& \left(p_{H}-p_{L}\right)\left(1-\phi_{E}-\phi_{I}\right) R(x) \geq(1-\gamma) \delta(C) R(x) \\
& \left(p_{H}-p_{L}\right) \phi_{I} R(x) \geq C R(x)
\end{array}
$$

The objective function represents the payoff of the inventor. The first term represents the inventor's dividends from the expected cash flows of the foreign production facility. The second term represents the gross return from investing his wealth $W$ minus the date- 0 transfer $F$ in the Home market. ${ }^{13}$ The last term represents the monitoring costs.

The first constraint is a financing constraint. Since the local entrepreneur has no wealth, his ability to invest at date 1 is limited by the sum of the external investors'

\footnotetext{
${ }^{12}$ We focus on an interpretation of payoffs resembling the payoffs of an equity contract, but the model is not rich enough to distinguish our optimal contract from a standard debt contract. Our results would survive in a model in which agents randomized between using equity and debt contracts. In any case, we bear this in mind in the empirical section of the paper, where we test the predictions of the model.

${ }^{13}$ We assume throughout that $W$ is large enough to ensure that $W-F \geq 0$ in equilibrium.
} 
financing $E$ and the cofinancing $F$ by the inventor. The second inequality is the participation constraint of external investors, who need to earn at least an expected gross return on their investments equal to 1. Similarly, the third inequality is the participation constraint of the foreign entrepreneur, given his zero outside option. The fourth inequality is the foreign entrepreneur's incentive compatibility constraint. This presumes that it is in the interest of the inventor to design a contract in a way that induces the foreign entrepreneur to behave. In Appendix A.2, we show that this will necessarily be the case provided that $\gamma$ is sufficiently large. The final constraint is the inventor's incentive compatibility constraint: if this condition was not satisfied, the inventor's payoff would be lower when exerting the monitoring level $\tilde{C}$ than when not doing so. ${ }^{14}$

In the program above, constraint (iii) will never bind. Intuitively, as is standard in incomplete information problems, the incentive compatibility constraint of the entrepreneur demands that this agent obtains some informational rents in equilibrium, and thus his participation constraint is slack. Conversely, the other four constraints will bind in equilibrium. This is intuitive for the financing constraint (i) and the participation constraint of investors (ii). It is also natural that the optimal contract from the point of view of the inventor will seek to minimize the (incentive-compatible) equity share accruing to the foreign entrepreneur, which explains why constraint (iv) binds.

It is perhaps less intuitive that constraint (v) also binds, indicating that the optimal contract minimizes the equity share $\phi_{I}$ allocated to the inventor. In particular, it may appear that a large $\phi_{I}$ would be attractive because it may foster a larger level of cofinancing $F$ at date 0, thereby encouraging investment. However, inspection of constraint (iv) reveals that a larger $\phi_{I}$ decreases the ability of the entrepreneur to borrow from external investors, as it reduces his pleadgeable income. Overall, one can show that, for a given level of monitoring, whether utility is transferred through an equity share or a date-0 lump-sum payment has no effect on the scale of the project. In addition, it is clear from the objective function that the inventor strictly prefers a date- 0 lump-sum transfer since he can use these funds to invest domestically and obtain a gross rate of return $\beta>1$ on them. Hence, the minimal incentive-compatible inventor equity share $\phi_{I}$ is optimal.

With these results at hand, it is immediate from constraint (v) that the optimal equity stake held by the inventor will be given by:

$$
\tilde{\phi}_{I}=\frac{\tilde{C}}{p_{H}-p_{L}},
$$

\footnotetext{
${ }^{14}$ Our derivation of this IC constraint assumes that if the inventor deviates from $\tilde{C}$, it does so by setting $C=0$ (which for large enough $\bar{\delta}$ would lead to a violation of the entrepreneur's incentive compatibility constraint). This is without loss of generality because any other deviation $C>0$ is dominated.
} 
which will be positive as long as $\tilde{C}$ is positive. In addition, manipulation of the first-order conditions of program (P1) delivers the following expression that implicitly determines the level of monitoring (see Appendix A.2 for details)

$$
-\delta^{\prime}(\tilde{C})=\frac{\beta p_{H}-p_{L}}{(1-\gamma) \beta p_{H}}
$$

Straightforward differentiation of equation (3) together with the convexity of the function $\delta(\cdot)$ produces the following result:

Lemma 1 The amount of monitoring $\tilde{C}$ is decreasing in both investor protection $\gamma$ in Foreign and in the inventor's shadow value of cash $\beta$.

The effect of investor protection on monitoring is intuitive. Given our specification of the private benefit function $B(\cdot)$ in $(1)$, the marginal benefit from monitoring is larger, the less developed is the financial system in Foreign (the lower is $\gamma$ ). Because the marginal cost of monitoring is independent of $\gamma, \tilde{C}$ and $\gamma$ are negatively correlated in the optimal contract.

The effect of the shadow value of cash $\beta$ on monitoring is a bit more subtle. The intuition behind the result lies in the fact that the larger is $\beta$, the larger is the opportunity cost of remunerating the inventor through ex-post dividends rather than through an exante lump-sum transfer. Because of the tight mapping between $\tilde{\phi}_{I}$ and $\tilde{C}$ imposed by the incentive compatibility constraint in $(\mathrm{v})$, we have that a larger $\beta$ is also associated with a higher shadow cost of monitoring, and hence with a lower optimal amount of monitoring.

In light of equation (2), it is clear that our theory has implications for the share of equity held by the inventor that relate closely to the implications for monitoring. In particular, $\tilde{\phi}_{I}$ is proportional to the level of monitoring $\tilde{C}$ and thus is affected by the parameters $\gamma$ and $\beta$ in the same way as is monitoring. This reflects that equity shares emerge in our model as incentives for the inventor to monitor the foreign entrepreneur. As a result, we can establish that:

Proposition 1 The share of equity held by the inventor is decreasing both in investor protection $\gamma$ in Foreign and in the inventor's shadow value of cash $\beta$.

An immediate corollary of this result is:

Corollary 1 Suppose that a transaction is recorded as an FDI transaction only if $\tilde{\phi}_{I} \geq$ $\underline{\phi_{I}}$. Then, there exist a threshold investor protection $\gamma^{*} \in[0,1]$ such that the optimal contract entails FDI only if $\gamma<\gamma^{*}$. 
Our theory thus predicts that the prevalence of FDI in a given country should, other things equal, be a decreasing function of the level of investor protection in that country.

Manipulation of the first-order conditions of program (P1) also delivers an implicit function of the level of investment as a function of parameters and the optimal level of monitoring $\tilde{C}$ :

$$
R^{\prime}(\tilde{x})=\frac{1}{p_{H}\left(1-\frac{(1-\gamma) \delta(\tilde{C})}{p_{H}-p_{L}}-\left(\frac{\beta p_{H}-p_{L}}{p_{H}-p_{L}}\right) \frac{\tilde{C}}{\beta p_{H}}\right)} .
$$

Equation (4) implicitly defines the level of expected sales by the firm, i.e., $p_{H} R(\tilde{x})$. Differentiating this equation with respect to $\gamma$ and $\beta$ we obtain (see Appendix A.3 for details):

Proposition 2 Output and cash flows in Foreign are increasing in investor protection $\gamma$ in Foreign and decreasing in the inventor's shadow value of cash $\beta$.

The intuition for the effect of investor protection is straightforward. Despite the fact that the inventor's monitoring reduces financial frictions, both the foreign entrepreneur's compensation, as dictated by his incentive compatibility constraint (iv), and monitoring costs are increasing in the scale of operation. In countries with weaker investor protections, the perceived marginal cost of investment is higher, thus reducing equilibrium levels of investment.

Using constraints (i), (ii), and (iv), one can also obtain the terms of the optimal financial contract with external investors in terms of $\tilde{C}$ and $\tilde{x}$ :

$$
\begin{aligned}
\tilde{\phi}_{E} & =1-\frac{(1-\gamma) \delta(\tilde{C})}{p_{H}-p_{L}}-\frac{\tilde{C}}{p_{H}-p_{L}} \\
\tilde{E} & =p_{H} \tilde{\phi}_{E} R(\tilde{x}) .
\end{aligned}
$$

Finally, straightforward manipulation delivers an optimal lump-sum date-0 transfer equal to:

$$
\tilde{F}=\frac{p_{L}}{\beta\left(p_{H}-p_{L}\right)} \tilde{C} R(\tilde{x})-\left(\frac{R(\tilde{x})}{R^{\prime}(\tilde{x}) \tilde{x}}-1\right) \tilde{x} .
$$

Depending on parameter values, the lump-sum transfer can be positive or negative and it also varies non-monotonically with the parameters of the model. We can, however, derive sharper predictions for the share of financing that is provided by the inventor. To see this, focus on the case in which the date- 0 payment $\tilde{F}$ is positive and can be interpreted as the level of cofinancing by the inventor. The share of investment financed by the inventor is then given by

$$
\frac{\tilde{F}}{\tilde{x}}=\frac{p_{L}}{\beta\left(p_{H}-p_{L}\right)} \tilde{C} \frac{R(\tilde{x})}{\tilde{x}}-\left(\frac{1-\alpha(\tilde{x})}{\alpha(\tilde{x})}\right),
$$


where $\alpha(x) \equiv x R^{\prime}(x) / R(x)$ is the elasticity of revenue to output. As mentioned above, when preferences feature a constant elasticity of substitution across a continuum of differentiated goods produced by different firms, $\alpha(x)$ is in independent of $x$, and $R(x)$ can be written as $R(x)=A x^{\alpha}$, where $A>0$ and $\alpha \in(0,1)$.

Notice that the first term in (5) is increasing in $\tilde{C}$ and decreasing in $\tilde{x}$ due to the concavity of $R(x)$. It thus follows from Lemma 1 and Proposition 2 that this first term is necessarily decreasing in $\gamma$. As for the second term, it will increase or decrease in $\tilde{x}$ depending on the properties of $\alpha(x)$. In most applications, $\alpha(x)$ will be either independent of $x$ or decreasing in $x$ (e.g., when the firm faces a linear demand function). In those situations, the second term in (5) will also be decreasing in $\gamma$ and we can conclude that:

Proposition 3 Provided that $\alpha^{\prime}(\tilde{x})$ is sufficiently small, the share of inventor financing in total financing $(\tilde{F} / \tilde{x})$ is decreasing in investor protection $\gamma$.

The intuition behind the result is that monitoring by inventors has a relatively high marginal product in countries with weak financial institutions. To induce the inventor to monitor, the optimal contract specifies a relatively steeper payment schedule, with a relatively higher contribution by the inventor at date 0 (a higher $\tilde{F} / \tilde{x}$ ) in anticipation of a higher share of the cash flows generated by the project at date 2 (a higher $\left.\tilde{\phi}_{I}\right) .{ }^{15}$

The fact that the monitoring provided by the inventor is unverifiable by third parties is central to our theory of FDI. In particular, if monitoring was verifiable (and thus contractible), the optimal contract analogous to the one described above would immediately imply an equity share for the inventor equal to zero (see Antràs, Desai and Foley, 2007, for details). Hence, the inventor would never choose to deploy her technology abroad through FDI. Instead, the inventor would sell the technology to the foreign entrepreneur in exchange for a positive lump-sum fee (and, hence, the inventor would never cofinance the project).

In section 4, we present empirical tests of Propositions 1, 2, and 3, and Corollary 1. Appendix A.1 shows that Propositions 1, 2, and 3 continue to hold in a multi-country version of the model in which the statements apply to cross-sectional variation in investor protections. Our empirical tests exploit variation in the location of affiliates of U.S. multinational firms and analyze the effect of investor protections on proxies for $\tilde{x}, \tilde{\phi}_{I}$, and $\tilde{F} / \tilde{x}$. We identify the inventor in the model as being a parent firm and control for other

\footnotetext{
${ }^{15}$ The effect of the shadow value of cash on the ratio $\tilde{F} / \tilde{x}$ is ambiguous. A larger $\beta$ is associated with a lower monitoring level $\tilde{C}$ (Lemma 1), but also with a lower level of $\tilde{x}$ and thus a higher ratio $R(\tilde{x}) / \tilde{x}$ (Proposition 2). In addition, $\beta$ has an additional direct negative effect on the ratio. The overall effect is, in general, ambiguous.
} 
parameters of the model, such as the shadow value of cash $\beta$, the concavity of $R(x)$, the monitoring function $\delta(C)$ and the probabilities $p_{H}$ and $p_{L}$ by using fixed effects for each firm in each year and controlling for a wide range of host-country variables. Because our estimation employs parent-firm fixed effects, we are not able to test the predictions regarding the effect of $\beta$ in Propositions 1,2 , and 3.

\subsection{Generalizations}

Before proceeding to the empirical analysis, it is useful to consider the robustness of these results to more general environments. In particular, we consider the degree to which revenue-sharing might substitute for equity contracts, the possibility that private benefits and monitoring costs may be proportional to $x$ rather than $R(x)$, and the effects of introducing productive monitoring by external investors. The underlying analysis is provided in Appendix A.4.

In the model above, we assume that when the project fails it delivers a level of revenue equal to zero. Such an assumption greatly enhances tractability but suggests that revenuesharing contracts may provide similar benefits to equity arrangements. This is problematic because it blurs the mapping between $\phi_{I}$ in the model and equity shares in the data. More generally, however, revenue-sharing contracts are not optimal when the project delivers a positive level of revenue in case of failure. In fact, a simple contract in which external investors are issued secured (or risk-free) debt and the inventor and entrepreneur take equity stakes is optimal. ${ }^{16}$ To see the intuition for this, consider the same setup as in section 2.1 but now assume that, when the project does not perform, it yields a level of revenue equal to $\underline{R}(x) \in(0, R(x))$. As is standard in moral hazard problems with risk-neutral agents, the optimal contract calls for the agents undertaking unobservable actions (e.g., effort decisions) to be maximally punished (subject to the limited liability constraint) whenever a failure of the project is observed. In our particular setup, this would imply that the optimal contract yields both the inventor and the entrepreneur a payoff of zero whenever a project failure is observed. The entire revenue stream $\underline{R}(x)$ should accrue to external investors.

A straightforward way to implement such a contract is for the entrepreneur to issue an amount of secure debt equal to $\underline{R}(x)$ to external investors and for the inventor and entrepreneur to be equity holders. Once the debt is paid, the inventor and entrepreneur receive a share of zero in case of project failure and a share of the amount $R(x)-\underline{R}(x)$ in

\footnotetext{
${ }^{16} \mathrm{~A}$ contract in which entrepreneur issues debt to external investors appears to have empirical validity because most capital provided to affiliates from local sources takes the form of debt.
} 
case of project success. The determination of their optimal shares is analogous to that in section 2.1 with $R(x)-\underline{R}(x)$ replacing $R(x)$ (details available upon request). In this more general setting, it is not possible to implement this optimal allocation of payoffs across agents through simple revenue-sharing arrangements. As such, the model can explain why an equity-like instrument tends to dominate both fixed-fee and revenue-sharing contracts in financially underdeveloped countries. Such contracts will likely entail an inefficiently low punishment to the inventor when the project does not perform well.

We next briefly discuss alternative formulations for the entrepreneur's private benefit of misbehavior and the inventor's private cost of monitoring. We have assumed above that these are proportional to the revenue generated by the project in case of success. If instead we specified them as being proportional to $x$, then the optimal equity share $\tilde{\phi}_{I}$ would be given by

$$
\tilde{\phi}_{I}=\frac{\tilde{C}}{\left(p_{H}-p_{L}\right)} \frac{\tilde{x}}{R(\tilde{x})},
$$

and would also depend on $\tilde{x}$ and the concavity of the $R(\tilde{x})$ function. One may thus worry that for a sufficiently concave $R(\tilde{x})$ function, it could be the case that equity stakes could be low in low $\gamma$ countries on account of the low values of $\tilde{x} / R(\tilde{x})$ in those countries. We show in Appendix A.4, however, that our main comparative static concerning equity shares holds as long as the elasticity of revenue with respect to output - that is $\alpha(\tilde{x}) \equiv$ $\tilde{x} R^{\prime}(\tilde{x}) / R(\tilde{x})$ - does not increase in $\tilde{x}$ too fast. The required condition is analogous to that in Proposition 3 and is satisfied for the case of constant price-elasticity and linear demand functions.

We finally consider the possibility that local external investors (e.g., banks) also provide useful monitoring, the productivity of which may also be higher in countries with worse investor protections. In Appendix A.4, we develop an extension of the model which incorporates monitoring by external investors that, as with the monitoring by the inventor, is subject to declining marginal benefits. Although the optimal contract is now more complicated, we show that the incentive compatibility constraint for the inventor will continue to bind in equilibrium, implying that the inventor's equity stake moves proportionally with its level of monitoring. Furthermore, provided that the level of investor protection $\gamma$ is sufficiently high, the analysis remains qualitatively unaltered by the introduction of local monitoring. The reason for this is that for large values of $\gamma$, the optimal contract already allocates equity stakes $\phi_{E}$ to external investors that are large enough to induce them to monitor the entrepreneur. ${ }^{17}$ As a result, although certain details of the

\footnotetext{
${ }^{17}$ When the level of investor protection is below a certain threshold, then the incentive compatibility for external investors becomes binding, in which case the analysis becomes more complicated. Without
} 
optimal contract change with the possibility of local monitoring, the comparative static results derived in section 2.2 continue to hold in this more general model provided that $\gamma$ is sufficiently large.

\section{$3 \quad$ Data and Descriptive Statistics}

The empirical work presented in section 4 is based on the most comprehensive available data on the activities of U.S. multinational firms and on arm's length technology transfers by U.S. firms. The Bureau of Economic Analysis (BEA) annual survey of U.S. Direct Investment Abroad from 1982 through 1999 provides a panel of data on the financial and operating characteristics of U.S. firms operating abroad. U.S. direct investment abroad is defined as the direct or indirect ownership or control by a single U.S. legal entity of at least ten percent of the voting securities of an incorporated foreign business enterprise or the equivalent interest in an unincorporated foreign business enterprise. A U.S. multinational entity is the combination of a single U.S. legal entity that has made the direct investment, called the U.S. parent, and at least one foreign business enterprise, called the foreign affiliate. ${ }^{18}$ The most extensive data for the period examined in this study are available for 1982, 1989, 1994, and 1999 when BEA conducted Benchmark Surveys. Accordingly, the analysis is restricted to benchmark years except when the annual frequency of the data is critical - in the analysis of scale in section 4.3 that uses the liberalizations of ownership restrictions.

In order to analyze arm's length technology transfers, measures of royalty payments, licensing fees, and other payments for intangible assets received by U.S. firms from unaffiliated foreign persons are drawn from the results of BEA's annual BE-93 survey. This survey requires that all firms receiving payments above certain thresholds to report, regardless of whether the firm is a multinational. ${ }^{19}$ Table I provides descriptive statistics for the variables used in the analysis employing the benchmark year data (Panel A) and analysis employing the full panel (Panel B).

Implementing empirical tests requires mapping the variables of the model to reasonable proxies in the data. In order to investigate the choice of an inventor to engage in arm's

imposing particular functional forms on the monitoring functions, it becomes impossible to derive sharp comparative static results (see Appendix A.4).

${ }^{18}$ Coverage and methods of the BEA survey are described in Desai, Foley and Hines (2002). The survey covers all countries and industries, classifying affiliates into industries that are roughly equivalent to three digit SIC code industries. As a result of confidentiality assurances and penalties for noncompliance, BEA believes that coverage is close to complete and levels of accuracy are high.

${ }^{19}$ Because these data have been collected since 1986, data used in the analysis of arm's length technology transfers cover only 1989, 1994, and 1999. 
length technology transfer or FDI (Corollary 1), the analysis uses a dummy variable that is equal to one if a U.S. firm receives an arm's length royalty payment from a country in a given year and zero if that firm only serves the country through affiliate activity in a particular year. For Proposition 3's predictions on the share of inventor financing in total financing $(\tilde{F} / \tilde{x})$ a variable is defined as the ratio of the sum of parent provided and equity debt to affiliate assets. Specifically, this share is the ratio of the sum of parent provided equity and net borrowing by affiliates from the parent to affiliate assets. ${ }^{20}$ Proposition 1 considers the determinants of the share of equity held by the inventor, $\phi_{I}$, and this variable is measured in the data as the share of affiliate equity owned by the multinational parent. The log of affiliate sales is used to test Proposition 2's predictions on the scale of affiliate activity.

Table I also provides descriptive statistics for a number of other variables. Two measures of investor protections and capital market development are used in the analysis below. As the model emphasizes the decisions of local lenders, the first measure is creditor rights. This measure is drawn from Djankov, McLiesh, and Shleifer (2007), which extends the sample studied in La Porta, Lopez-de-Silanes, Shleifer, and Vishny (1998) to cover a broader sample of countries over the 1982-1999 period on an annual basis. Creditor rights is an index taking values between 0 and 4 and measures the extent to which the legal system constrains managers from diverting value away from creditors (as a large $\gamma$ does in the model). ${ }^{21}$ The second measure is the annual ratio of private credit provided by deposit money banks and other financial institutions to GDP, and it is drawn from Beck, Demirguc-Kunt, and Levine (1999). This measure has the advantage of being an objective, continuous measure of the lending environment which captures the willingness of lenders to provide credit in response to investor protections. ${ }^{22}$

\footnotetext{
${ }^{20}$ In the model, we have interpreted all sources of financing as equity financing, but as explained in footnote 12 , our setup is not rich enough to distinguish equity financing from debt financing. Hence, our empirical tests of Proposition 5 include both.

${ }^{21}$ Specifically, the measure is an index formed by adding 1 when: (1) the country imposes restrictions, such as creditors' consent or minimum dividends to file for reorganization; (2) secured creditors are able to gain possession of their security once the reorganization petition has been approved (no automatic stay); (3) secured creditors are ranked first in the distribution of the proceeds that result from the disposition of the assets of a bankrupt firm; and (4) the debtor does not retain the administration of its property pending the resolution of the reorganization.

${ }^{22}$ It is possible to employ a measure of shareholder rights to measure investor protections. Creditor rights and private credit are used to measure investor protections for several reasons. First, shareholder rights are only available for a single year near the end of our sample. Second, in our data, there is very little local ownership of affiliate equity, but affiliates do make extensive use of debt borrowed from local sources. As such, using creditor rights and private credit allows us to capitalize on some time series variation in investor protections and more closely corresponds empirically to the financing choices of affiliates.
} 
Measures of capital market development are correlated with other measures of economic and institutional development that could affect the outcome studied in ways not considered in the model. Therefore, the regressions control for several measures of economic and institutional variation that might otherwise obscure the analysis. The baseline specifications include controls for FDI ownership restrictions, human capital development, the log of GDP, the log of GDP per capita, and corporate tax rates. A number of countries impose restrictions on the extent to which foreign firms can own local ones. Shatz (2000) documents these restrictions using two distinct measures that capture restrictions on greenfield FDI and cross-border mergers and acquisition activity. The FDI ownership restriction dummy used below is equal to one if either of these measures is below three and zero otherwise.

Countries with more human capital, with more economic activity, or with a higher level of economic development may be more able to use technology obtained through an arm's length transfer, and affiliates in these countries may exhibit distinctive financing patterns that reflect the quality of local entrepreneurs as opposed to financial market conditions. To address these possibilities, the specifications include workforce schooling, which measures the average schooling years in the population over 25 years old and is provided in Barro and Lee (2000). Data on the log of GDP and the log of GDP per capita come from the World Development Indicators. Firms could avoid local production or alter their financing patterns in response to tax considerations. Corporate tax rates are imputed from the BEA data by taking the median tax rate paid by affiliates that report positive net income in a particular country and year.

Several other controls appear in additional specifications. Firms might chose to deploy technology through affiliate activity as opposed to through an arm's length transfer, and they might select higher levels of ownership if they fear expropriation by local entrepreneurs (see, for instance, Ethier and Markusen, 1986 for a theoretical treatment). Ginarte and Park (1997) provide a measure of the strength of patent protections, and the Index of Economic Freedom provides a measure of more general property rights. Rule of law is an assessment of the strength and impartiality of a country's legal system, and it is drawn from the International Country Risk Guide (ICRG). Additionally, firms might fear expropriation by foreign governments and might limit foreign activity and make more extensive use of local financing in response. The ICRG also provides an index of the risk of outright confiscation or forced nationalization faced by foreign investors. For this measures, higher values indicate lower risks. ${ }^{23}$

\footnotetext{
${ }^{23}$ Some country-level measures of economic and institutional development are highly correlated. The multicollinearity of these variables might cause the standard errors of our key estimates to be large.
} 
Since the BEA data are a panel measuring activity of individual firms in different countries, they allow for the inclusion of effects for each firm in each year, which we refer to as parent-year fixed effects. These fixed effects help control for other parameters of the model that are likely to be specific to particular firms at particular points in time, such as the shadow value of cash $\beta$, the concavity of $R(x)$, the monitoring function $\delta(C)$ and the probabilities $p_{H}$ and $p_{L}$. The inclusion of these fixed effects imply that the effects of investor protections are identified off of within firm variation in the characteristics of countries in which the firm is active.

While the comprehensive data on multinational firms and arm's length technology transfers does offer a number of advantages, it is worth noting one significant oversight. Neither the model nor the empirical work considers situations in which a firm neither invests in nor transfers technology to a particular location.

\section{Empirical Results}

Each of the analyses below is comprised of a descriptive figure and firm-level regressions. The figures provide a transparent and intuitive perspective on the predictions, and the regressions allow for a full set of controls and subtler tests emphasizing the role of technology intensity. The predictions on the use of arm's length technology transfers and the financing and ownership of foreign affiliates are investigated by pooling cross-sections from the benchmark years. Investigating the effect on scale requires an alternative setup as controlling for the many unobservable characteristics that might determine firm size is problematic. Fortunately, the model provides a stark prediction with respect to scale that can be tested by analyzing responses to the easing of ownership restrictions.

\subsection{Arm's Length Technology Transfer Decisions}

Figure I provides a preliminary perspective on the extent to which firms deploy technology through arm's length transfers relative to direct ownership, across different quintiles of the private credit measure of investor protections. The propensity to use arm's length technology transfer is computed at the country-year level as the ratio of the number of firms that receive a royalty payment from an unaffiliated foreign person to the number of firms that either receive such an arm's length royalty or have an affiliate. The average arm's length royalty share is 0.11 for the lowest private credit quintile of observations while it is 0.27 for the highest quintile. As predicted by the theory, firms appear to make

However, these coefficient estimates remain unbiased. 
greater use of arm's length technology transfers, relative to direct ownership, to access countries with more developed capital markets.

Table II further explores arm's length technology transfers through specifications that include various controls and incorporate subtler tests. The dependent variable in these tests, the Arm's Length Technology Transfer Dummy, is defined for country-year pairs in which a firm either has an affiliate or receives a royalty payment from an unaffiliated foreign person. The dummy is equal to one if the firm receives a royalty payment from an unaffiliated foreign person, and it is otherwise equal to zero. The inclusion of parent-year fixed effects controls for a variety of unobservable firm characteristics that might otherwise conflate the analysis. All specifications presented in the table also include a measure of the existence of foreign ownership restrictions, workforce schooling, the log of GDP, the log of GDP per capita, and host country tax rates. ${ }^{24}$ Standard errors are heteroskedasticityconsistent and are clustered at the country-year level. These specifications are linear probability models and are used in order to allow for both parent-year fixed effects and for clustering of standard errors at the country-year level. ${ }^{25}$

The coefficient on creditor rights in column 1 is positive and significant, affirming the prediction of Corollary 1 that firms are more likely to serve countries with higher levels of investor protections through arm's length technology transfer as opposed to only through a foreign affiliate. The results also indicate that firms are more likely to engage in arm's length technology transfer as opposed to just affiliate activity in countries that have a more educated workforce and that have higher corporate tax rates.

The predictions of the model relate to credit market development, but the measure of creditor rights may be correlated with more general variation in the institutional environment. The specification presented in column 2 includes additional proxies for the quality of other host country institutions including indices of patent protections, property rights, the strength and impartiality of the overall legal system, and the risk of expropriation as control variables. The coefficient on creditor rights remains positive and significant with the inclusion of these additional controls, implying that capital market conditions play an economically significant role relative to other host country institutions. The effect of a one standard deviation change in creditor rights is approximately one and a half times as large as the effect of a one standard deviation change in patent protections, which is

\footnotetext{
${ }^{24}$ In order for the estimated effects of capital market conditions to be unbiased in this and the subsequent tests, these country characteristics must be exogenous to firm decisions to use arm's length technology transfers as opposed to FDI, and firm financing and ownership decisions.

${ }^{25}$ Given the limited time dimension of our dataset, our linear specification avoids the incidental parameter problem inherent in the estimation of a large number of fixed effects. As a robustness check, these specifications have been run as conditional logit specifications. The resulting coefficients on the measures of financial development are of the same sign and statistical significance as those presented in Table II.
} 
also positive and significant in explaining the use of arm's length technology transfer.

The specification presented in column 3 provides a more subtle test of the model and the particular mechanism that gives rise to FDI as opposed to arm's length technology transfer. The model implies that the relative value of monitoring should be more pronounced for firms that conduct more research and development (R\&D) because these firms are more likely to be deploying novel technologies that require the unique monitoring ability of parents. Alternatively, firms with limited technological capabilities are less likely to be important to external funders as monitors, and the effects of capital market development on the choice to serve a country through arm's length technology transfer or affiliate activity should be less pronounced for these kinds of firms.

The specification presented in Column 3 uses the log of parent R\&D as a proxy for the degree to which firms are technologically advanced. Since this specification includes parent-year fixed effects, this variable does not enter on its own, but it is interacted with creditor rights. ${ }^{26}$ The positive coefficient on the interaction term is consistent with the prediction that the value of creating incentives to monitor through ownership in countries with weak financial development is highest for technologically advanced firms.

The specifications presented in columns 4-6 of Table II repeat those presented in columns 1-3 replacing creditor rights with private credit as a measure of financial development. The positive and significant coefficients on private credit in columns 4 and 5 are consistent with the findings in columns 1 and 2 and illustrate that countries with higher levels of financial development are more likely to be served through arm's length technology transfers as opposed to just affiliate activity. The positive and significant coefficient on private credit interacted with the log of parent R\&D presented in column 6 indicates that the effects of capital markets are most pronounced for firms that are R\&D intensive. $^{27}$

\subsection{The Financing and Ownership of Foreign Affiliates}

The analysis presented in Figure II and Table III investigates if financing and ownership decisions reflect the dynamics emphasized in the model. As depicted in Figure II, parent

\footnotetext{
${ }^{26}$ If the measure of parent technology intensity were included on its own, its coefficient would be subject to endogeneity concerns. Because parent characteristics are absorbed by the parent/year fixed effects, the coefficient on this interaction term picks up how the effect of capital market conditions varies across firms. The sample used in this specification and the specification in column 6 includes only multinational firms because R\&D expenditures are only available in the BEA data for these firms.

${ }^{27}$ When running these specifications as conditional logit specifications, the resulting coefficients on these interaction terms are of the same sign and statistical significance as those in the Table II, except for the interaction of creditor rights and the log of parent $R \& D$. The coefficient on this variable is positive, but it is not statistically different from zero at conventional levels.
} 
firms provide financing that averages $45 \%$ of affiliate assets in countries in the lowest quintile of private credit but $38 \%$ of affiliate assets in countries from the highest quintile of private credit. $^{28}$ Table III presents the results of more detailed tests of this relation. In addition to a variety of country-level controls, fixed effects for each parent in each year control for differences across firms. The negative and significant coefficient on creditor rights in column 1 indicates that the share of affiliate assets financed by the parent is higher in countries that do not provide creditors with extensive legal protections. This result is consistent with the prediction contained in Proposition 3, and the pattern depicted in Figure II.

The specification in column 2 includes the set of other institutional variables also used in Table II to ensure that proxies for financial development are not proxying for some other kind of institutional development. In addition, this specification also controls for affiliate characteristics that the corporate finance literature suggests might influence the availability of external capital. Harris and Raviv (1991) and Rajan and Zingales (1995) find that larger firms and firms with higher levels of tangible assets are more able to obtain external debt. Two proxies for affiliate size - the log of affiliate sales and the log of affiliate employment - and a proxy for the tangibility of affiliate assets - the ratio of affiliate net property, plant and equipment to affiliate assets - are included. ${ }^{29}$

In the specification in column 2 , the -0.0164 coefficient on creditor rights implies that the share of affiliate assets financed by the affiliate's parent is 0.0327 , or $7.9 \%$ of its mean value, higher for affiliates in countries in the 25 th percentile of creditor rights relative to the 75 th percentile of creditor rights. The negative and significant coefficient on FDI ownership restrictions is consistent with the hypothesis that such restrictions limit parent capital provisions, and the negative and significant coefficient on the log of GDP suggests that affiliates located in smaller markets are more reliant on their parents for capital. When affiliates borrow, they primarily borrow from external sources, and Desai, Foley and Hines (2004b) shows that affiliates borrow more in high tax jurisdictions. These facts could explain the negative coefficient on the corporate tax rate in explaining the share of assets financed by the parent. ${ }^{30}$ Previous theoretical work stressing how concerns

\footnotetext{
${ }^{28}$ More specifically, the values displayed in this chart are computed by first taking average shares of affiliate assets financed by parents for each country in each year. These shares are defined as the ratio of the sum of net borrowing from the parent and parent equity provisions (including both paid-in-capital and retained earnings) to affiliate assets. The bars display medians of the country level averages for each quintile of private credit.

${ }^{29}$ The affiliate controls included in this specification as well as those in columns 3,5 , and 6 of Table III and columns 2, 3, 5, and 6 of Table IV are potentially endogenous. It is comforting that their inclusion does not typically have a material impact on the estimated effects of capital market conditions.

${ }^{30}$ The model's predictions relate to overall parent capital provision. As such, these specifications differ from the analysis in Desai, Foley and Hines (2004b) where only borrowing decisions are analyzed.
} 
over technology expropriation might give rise to multinational activity does not make clear predictions concerning the share of affiliate assets financed by the parent, but it is worth noting that the indices of patent protection and property rights are negative in the specification in column 2. None of the unreported coefficients on affiliate characteristics are significant.

If parent financing creates incentives for monitoring and the effects of monitoring are strongest for firms with more technology, then the effects documented in column 2 should be most pronounced for R\&D intensive firms. The specification in column 3 tests for a differential effect of creditor rights on financing by including creditor rights interacted with the log of parent R\&D. The negative and significant coefficient on this interaction term indicates that more technologically advanced firms finance a higher share of affiliate assets in countries with weak credit markets. This finding is not implied by many other intuitions for why investor protections might affect parental financing provisions.

The specifications presented in columns 4-6 of Table III repeat the analysis presented in columns 1-3 substituting measures of private credit for creditor rights. In columns 4 and 5 , the coefficient on private credit is negative, and it is significant in column 4 but only marginally significant in column 5 . In the specification in column 6 , the interaction of private credit and the log of parent R\&D is significant. The results obtained when using private credit are also consistent with the prediction of Proposition 3 and with Figure II.

The model also predicts that multinational parents should hold larger ownership stakes in affiliates located in countries with weak investor protections. Table IV presents results of using the share of affiliate equity owned by the parent as the dependent variable in specifications that are similar to those presented in Table III. Although parent equity shares are bounded between 0 and 1 , and there is a large grouping of affiliates with equity that is $100 \%$ owned by a single parent firm, the specifications presented in Table IV are ordinary least squares models that include parent-year fixed effects and that allow standard errors to be clustered at the country-year level. ${ }^{31}$ In the specifications presented in columns $1,2,4$, and 5 , the proxy for credit market development is negative and significant. Parent companies own higher shares of affiliate equity when affiliates are located in countries where protections extended to creditors are weaker and private credit is scarcer, as predicted by the model. In the specifications presented in columns 3 and 6 , the negative and significant coefficients on the interaction terms indicate that these results are also more pronounced for technologically advanced firms.

\footnotetext{
${ }^{31}$ Wholly-owned affiliate comprise $77.2 \%$ of all observations. These results are robust to using an alternative estimation technique. Conditional logit specifications that use a dependent variable that is equal to one for wholly owned affiliates and zero for partially owned affiliates yield similar results.
} 
The results in Table IV also indicate that equity ownership shares are lower in countries with ownership restrictions and countries with higher corporate tax rates. If equity ownership decisions placed strong emphasis on the protection of technology and ownership substituted for weak patent protections, the coefficient on the Patent Protections variable should be negative and significant. While the estimated coefficient is negative, it is only marginally significant in some specifications.

The results presented in Tables II, III, and IV are robust to a number of concerns. First, it is possible that the estimates of coefficients on capital market conditions interacted with the log of parent $\mathrm{R} \& \mathrm{D}$ may reflect the effect of similar interactions with alternative institutional variables. In order to consider this possibility, it is useful to consider the inclusion of other interaction terms. For example, when the log of parent R\&D interacted with the rule of law index is included in the specifications presented in columns 3 and 6 of the three tables, the interactions that include proxies for capital market development remain significant in all of the tests. When the log of parent R\&D interacted with the patent protection index is included in these specifications, the interactions featuring proxies for credit market development remain significant in all of the tests except for the one in column 3 of Table II. As such, it appears that the role of R\&D intensity is most pronounced through the channel emphasized in the model, through interactions with capital market conditions.

It may also be the case that the share of affiliate assets financed by the parent and parent ownership levels are lower for older affiliates and these affiliates may be more prevalent in countries with better investor protections. Including proxies for affiliate age in the specifications presented in the specifications presented in Tables III and IV does not affect the results of interest. ${ }^{32}$ Similarly, the model does not explicitly consider the possibility that a firm exploits its technology through trade as opposed to through FDI or arm's length technology transfers. To consider if trade channels could affect the main findings, the log of parent exports to unaffiliated foreign persons in each country and year is included as a control in each of the specifications. The magnitude and significance of the coefficients on the proxies for capital market conditions and the interactions of these proxies and the log of parent R\&D are not materially changed. Finally, contractual forms that are specific to the natural resources sector could affect some of the results. Removing observations of firms in this sector reduces the significance of the results on the effects of private credit in specifications presented in column 5 of Table II and Table III, but does not materially change any of the other results on the effects of capital market conditions

\footnotetext{
${ }^{32}$ The proxies for age are the number of years since an affiliate first reported data to BEA and a dummy equal to one if the affiliate first reported in 1982 and zero otherwise.
} 
in Tables II, III, and IV. ${ }^{33}$

\subsection{The Scale of Multinational Activity}

The model predicts that multinational activity will be of a larger scale in countries with stronger investor protections. Because there are many theories for the determinants of FDI activity, using specifications similar to those presented in Tables II, III, and IV to explore scale is problematic as it is difficult to include a set of controls sufficiently extensive to distinguish between alternative theories. ${ }^{34}$

Fortunately, a subtler prediction of the model allows for tests of scale effects. Specifically, the model suggests that the response to the liberalizations of ownership restrictions should be larger in host countries with weak investor protections. The intuition for this prediction is that in countries with weak investor protections, ownership restrictions are more likely to bind because ownership is most critical for maximizing the value of the enterprise in these settings. As such, the relaxation of an ownership constraint should have muted effects for affiliates in countries with deep capital markets and more pronounced effects for affiliates in countries with weaker investor protections. ${ }^{35}$

Figure III illustrates how the scale of multinational activity changes around the time of ownership liberalizations in countries with different levels of capital market development. Liberalizations are defined as the first year in which the FDI ownership restriction dummy described above changes from 1 to $0 .{ }^{36}$ The lines trace out an index that is computed by

\footnotetext{
${ }^{33}$ Firms in BEA industries 101-148 and 291-299 are dropped from the sample. The coefficient on private credit in column 5 of Table II, when estimated using the reduced sample, is 0.0292 , and it has a t-statistic of 1.92. The coefficient on private credit in column 5 of Table III, when estimated using the reduced sample, is -0.0351 , and it has a t-statistic of 1.62 .

${ }^{34}$ Appendix Table I in Antràs, Desai, and Foley (2007) presents the results of such an exercise. Although the coefficients on both the creditor rights variables and private credit variables are usually positive in explaining the $\log$ of affiliate sales, as Proposition 2 predicts, none of the coefficients on these variables is significant.

${ }^{35}$ This prediction can in fact be explicitly derived from the model. In particular, one can envision an ownership restriction as an additional constraint to program (P1) requiring that $\phi_{I} \leq \bar{\phi}_{I}$ for some foreign ownership cap $\bar{\phi}_{I} \in \mathbb{R}$. One can then show (details available upon request) that (i) for large enough $\gamma$, this constraint will not bind and thus a removal of the constraint will have no effects on affiliate activity; (ii) when the constraint binds, the level of affiliate activity $x$ is lower than in the absence of the constraint; and (iii) a marginal increase in $\bar{\phi}_{I}$ (i.e., a relaxation of the restriction) increases $x$ by more, the lower is $\gamma$. Hence, the response of affiliate activity to a removal of ownership restrictions will be relatively larger in countries with relatively weaker investor protections.

${ }^{36}$ The countries experiencing a liberalization are Argentina (1990), Australia (1987), Colombia (1992), Ecuador (1991), Finland (1990), Honduras (1993), Japan (1993), Malaysia (1987), Mexico (1990), Norway (1995), Peru (1992), Philippines (1992), Portugal (1987), Sweden (1992), Trinidad and Tobago (1994), and Venezuela (1990). Since control variables measuring the development of institutions other than credit markets do not vary much (if at all) through time and are unavailable for six of the sixteen reforming countries, these controls are not included in the analysis of liberalizations. The affiliate fixed effects
} 
calculating the ratio of aggregate affiliate sales in a particular country and year to the value of aggregate affiliate sales in that country in the year of liberalization. The line demarcated by squares (triangles) plots the average of this index across countries that have a measure of private credit in the year prior to the liberalization that is equal to or less than (above) the median private credit of liberalizing countries. The lines indicate that affiliate activity increases by a larger margin in countries with low levels of private credit following liberalizations.

The specifications presented in Table $\mathrm{V}$ investigate if these differential effects are robust. The dependent variable in columns 1 and 2 is the log value of affiliate sales, and the sample consists of the full panel from 1982 to 1999. Given the limited data requirements of these specifications (relative to the variables investigated in Tables II, III and IV) and the desire to investigate changes within affiliates, the full panel provides a more appropriate setting for these tests. These specifications include affiliate and year fixed effects and the standard errors are clustered at the country level. The sample includes all countries so affiliate activity in countries that do not liberalize helps identify the year effects and the coefficients on the income variables. The results are robust to using a sample drawn only from reforming countries.

The specifications in columns 1 and 2 include controls for log GDP, log GDP per capita and the post-liberalization dummy. The coefficient on log GDP per capita is positive and significant indicating that rising incomes are associated with larger levels of affiliate activity. The coefficient of interest in column 1 is the coefficient on the interaction of the post-liberalization dummy and a dummy that is equal to one if the country has a value of the creditor rights index in the year before liberalization that is equal to or less that the median value for liberalizing countries. The positive and significant coefficient indicates that affiliates in weak creditor rights countries grow quickly after liberalizations. The coefficient on the post-liberalization dummy on its own indicates that the effect of liberalizations is negligible and statistically insignificant for affiliates in high creditor rights countries. In column 2, these same results are obtained when the measure of private credit is used as the proxy for financial development. At the affiliate level, the model's predictions regarding how the scale of activity relates to capital market depth are validated using tests that, through the use of affiliate fixed effects and the emphasis on the interaction term, are difficult to reconcile with alternative theories.

It is possible that the results presented in columns 1 and 2 inaccurately capture the effects of the liberalizations because they only measure activity on the intensive margin and fail to capture responses on the extensive margin. Entry or exit might accompany

implicitly control for time invariant country characteristics so this is unlike to pose a significant problem. 
liberalizations and might amplify or dampen these results. Figure III suggests this is not the case because it is constructed using data aggregated to the country level. The specifications provided in columns 3 and 4 employ a dependent variable that is the $\log$ value of the aggregate value of all sales of U.S. multinational affiliates within a countryyear cell. These specifications substitute country fixed effects for affiliate fixed effects but are otherwise similar to the regressions provided in columns 1 and 2 .

In column 3, the coefficient on the interaction term including the creditor rights variable is again positive and significant indicating that incorporating activity on the extensive margin does not appear to contradict the earlier result. In column 4, the coefficient on the interaction term is again positive and significant. Taken together, the results suggest that the scale of activity is positively related to the quality of investor protections and capital market development, and these results persist when incorporating the effects of entry and exit.

\section{Conclusion}

Efforts to understand patterns of multinational firm activity have typically emphasized aspects of technology expropriation rather than the constraints imposed by weak investor protections and shallow capital markets. In the prior literature, multinational firms arise because of the risk of a partner expropriating a proprietary technology. In the model presented in this paper, the exploitation of technology is central to understanding multinational firm activity, but the critical constraint is the nature of capital market development and investor protections in host countries. Entrepreneurs must raise capital to fund projects, and external investors are aware of the possibility that these entrepreneurs might behave opportunistically. Inventors can alleviate financial frictions because they have privileged knowledge of their technology and can thus play a role in monitoring entrepreneurs. As a result, multinational firm activity and capital flows arise endogenously to ensure that monitoring occurs. External investors demand higher levels of multinational parent firm financial participation in countries with weak investor protections.

By placing financial frictions at the center of understanding patterns of activity and flows, the model delivers novel predictions about the use of arm's length technology transfers and about the financial and investment decisions of multinational firms that are validated in firm-level analysis. The use of arm's length technology transfers is more common in countries with strong investor protections and deep capital markets. Previous findings that FDI flows to developing countries are limited reflect two opposing forces. Weak investor protections and shallow capital markets limit the efficient scale of enterprise but 
also result in greater parent provision of capital and more parent ownership of affiliate equity. The effects of the institutional setting are more pronounced for R\&D intensive firms as parental monitoring is particularly valuable for the investments of these firms. By jointly considering operational and financial decisions, the theory and empirics provide an integrated explanation for patterns of MNC activity and FDI flows that have typically been considered separately.

Further consideration of the role of financial frictions on multinational firm activity along several dimensions may prove fruitful. First, the model presented effectively rules out exports to unrelated parties as a means of serving foreign markets. Incorporating the tradeoff between exports and production abroad in a world with financial frictions may yield additional predictions that would help explain the choice between exporting and FDI. Second, exploring the implications of financial frictions for intrafirm trade may help explain how the demands of external funders in weak institutional environments affect the fragmentation of production processes across borders. Finally, the central role of foreign ownership in reducing diversion may lead to significant variation in the relative competitiveness of local and foreign firms that reflects the institutional environment emphasized in this paper. 


\section{A Appendix}

\section{A.1 The Shadow Cost of Cash}

In the main text, we have treated the shadow value of cash $\beta$ as exogenous. In this Appendix we briefly illustrate how to endogenize it and show how it relates to characteristics of the Home country and in particular to its level of investor protection.

For this purpose, we generalize the setup described in section 2.1 and consider the situation in which there are $J-1$ Foreign countries, each associated with a level of financial development $\gamma^{j}$ and a cash flow function $R^{j}\left(x^{j}\right) \cdot{ }^{37}$ The inventor contracts with each of $J-1$ foreign entrepreneurs and, as a result of the optimal contracting described above, has an amount of cash equal to $W-\sum_{j \neq H} \tilde{F}^{j}$ to invest in the Home country.

Preferences and technology at Home are such that the cash flows obtained from the sale of the differentiated good at Home can be expressed as a strictly increasing and concave function of the quantity produced, $R^{H}(q)$, satisfying the same properties as the cash flow function in other countries. Home production is managed by the inventor, who can also privately choose to behave or misbehave, with consequences identical to those discussed above: if the inventor behaves, the project performs with probability $p_{H}$, but if he misbehaves, the project performs with a lower probability $p_{L}$. In the latter case, however, the inventor obtains a private benefit equal to a fraction $1-\gamma^{H}$ of cash flows, where $\gamma^{H}$ is an index of investor protection at Home.

The inventor sells domestic cash flow rights to a continuum of external investors at Home, who can obtain a rate of return equal to one in an alternative investment opportunity. ${ }^{38}$ We consider an optimal financial contract between the inventor and external investors in which the inventor is granted the ability to make take-it-or-leave-it offers, just as in the main text. The optimal contract specifies the scale of operation $x^{H}$, the amount of cash $W_{x}$ that the inventor invests in the project, the share of equity $\phi_{E}^{H}$ sold to external investors, and the amount of cash $E^{H}$ provided by external investors.

Taking the contracts signed with foreign individuals as given, an optimal financial contract with external investors at Home that induces the inventor to behave is given by the tuple $\left\{\tilde{x}^{H}, \tilde{W}_{x}, \tilde{\phi}_{E}^{H}, \tilde{E}^{H}\right\}$ that solves the following program:

$$
\begin{array}{cl}
\max _{x^{H}, W_{x}, \phi_{E}^{H}, E^{H}} & \Pi_{I}=\sum_{j \neq H}\left(\phi_{I}^{j} p_{H}-C^{j}\right) R^{j}\left(x^{j}\right)+p_{H}\left(1-\phi_{E}^{H}\right) R^{H}\left(x^{H}\right)+W-\sum_{j \neq H} \tilde{F}^{j}-W_{x} \\
\text { s.t. } & x^{H} \leq E^{H}+W_{x} \\
& W_{x} \leq W-\sum_{j \neq H} \tilde{F}^{j} \\
& p_{H} \phi_{E}^{H} R^{H}\left(x^{H}\right) \geq E^{H} \\
& \left(p_{H}-p_{L}\right)\left(1-\phi_{E}^{H}\right) R^{H}\left(x^{H}\right) \geq\left(1-\gamma^{H}\right) R^{H}\left(x^{H}\right)
\end{array}
$$

\footnotetext{
${ }^{37}$ With some abuse of notation we use $J$ to denote both the number of countries as well as the set of these countries.

${ }^{38}$ For simplicity, we assume that the inventor cannot pleadge foreign cash flow rights to its external investors.
} 
It is straightforward to show that provided that $\gamma^{H}$ is low enough (i.e, provided that financial frictions at Home are large enough), all constraints in program (P2) will bind in equilibrium, and the profits of the entrepreneur can be expressed

$$
\Pi_{I}=\sum_{j \neq H}\left(\phi_{I}^{j} p_{H}-C^{j}\right) R^{j}\left(x^{j}\right)+\widehat{\beta}\left(W-\sum_{j \neq H} \tilde{F}^{j}\right)
$$

where

$$
\hat{\beta}=\frac{\frac{1-\gamma^{H}}{\left(p_{H}-p_{L}\right)}}{\frac{1-\gamma^{H}}{p_{H}-p_{L}}-\left(1-\frac{\tilde{x}^{H}}{p_{H} R^{H}\left(\tilde{x}^{H}\right)}\right)}>1
$$

Notice that the resulting profit function (A1) is closely related to that considered in program (P2) in section 2.2 , where $\hat{\beta}$ now replaces $\beta$. There are however two important differences between the two profit functions.

First, the formulation in (A1) considers the case in which the inventor obtains cash flow from the exploitation of the technology in multiple countries. Nevertheless, notice that for a given $\hat{\beta}$, the profit function features separability between these different sources of dividends. As a result, for a given $\hat{\beta}$, the optimal contract with the entrepreneur and external investors in each country $j$ is as described in section 2.2. ${ }^{39}$ Hence, Propositions 1, 2, and 3 continue to apply and their statements not only apply to changes in the parameter $\gamma$, but also to cross-sectional (cross-country) variation in investor protection. In this sense, the tests performed in section 4 are well defined.

The second important difference between the profit function in (A1) and in program (P2) is that the shadow value of cash $\hat{\beta}$ is in fact endogenous, in the sense that it is a function of the scale of operation at Home $x^{H}$, which in turn will depend on the optimal contracts in the other $J$ countries through the date- 0 transfers $\tilde{F}^{j}$ for $j \neq H$ (as is clear from program (P2)). Hence, $\hat{\beta}$ will in general be a function of the vector of country investor protections $\gamma \equiv\left(\gamma^{1}, \ldots, \gamma^{J-1}, \gamma^{H}\right)$. Notice, however, that for large enough $J$, the effect of a particular investor protection level $\gamma^{j}(j \neq H)$ on the overall shadow value of cash $\hat{\beta}$ will tend to be negligible, and thus the comparative static results in section 2.2 will continue to apply.

To sum up, this Appendix has illustrated that a higher-than-one shadow value of cash can easily be rationalized in a simple extension of our initial partial-equilibrium model, in which not only foreign entrepreneurs, but also the inventor faces financial constraints. We have seen that endogenizing the shadow value of cash may affect the solution of the optimal contract in subtle ways, but that if the number of host countries in which the inventor exploits his technology is large enough, the comparative static results in section 2.2 remain qualitatively valid.

\footnotetext{
${ }^{39}$ Notice also that when $\hat{\beta}>1$, the inventor is financially constrained at Home, in the sense that external investors at Home are only willing to lend to him a multiple of his pleadgeable income (wealth plus date0 payments). If external investors were to lend a larger amount, the inventor's incentive compatibility constraint would be violated. The same would of course apply to external investors in foreign countries. This helps rationalize our assumption in section 2.1 that the inventor does not sign bilateral financial contracts with external investors in host countries.
} 


\section{A.2 Characterization of the Optimal Contract}

Let us start by writing the Lagrangian corresponding to program (P1). Letting $\lambda_{k}$ denote the multiplier corresponding to correspond to constraint $k=1,2,4,5$ (remember constraint (iii) cannot bind), we have

$$
\begin{aligned}
\mathcal{L}= & \phi_{I} p_{H} R(x)+(W-F) \beta-C R(x)+\lambda_{1}(E+F-x)+\lambda_{2}\left(p_{H} \phi_{E} R(x)-E\right) \\
& +\lambda_{4}\left(\left(p_{H}-p_{L}\right)\left(1-\phi_{E}-\phi_{I}\right)-(1-\gamma) \delta(C)\right)+\lambda_{5}\left(\phi_{I}-\frac{C}{\left(p_{H}-p_{L}\right)}\right) .
\end{aligned}
$$

The first-order conditions of this program (apart from the standard complementarity slackness conditions) are:

$$
\begin{aligned}
\frac{\partial \mathcal{L}}{\partial F} & =-\beta+\lambda_{1}=0 \\
\frac{\partial \mathcal{L}}{\partial \phi_{I}} & =p_{H} R(\tilde{x})-\lambda_{4}\left(p_{H}-p_{L}\right)+\lambda_{5}=0 \\
\frac{\partial \mathcal{L}}{\partial x} & =\tilde{\phi}_{I} p_{H} R^{\prime}(\tilde{x})-\tilde{C} R^{\prime}(\tilde{x})-\lambda_{1}+\lambda_{2} p_{H} \tilde{\phi}_{E} R^{\prime}(\tilde{x})=0 \\
\frac{\partial \mathcal{L}}{\partial \phi_{E}} & =\lambda_{2} p_{H} R(\tilde{x})-\lambda_{4}\left(p_{H}-p_{L}\right)=0 \\
\frac{\partial \mathcal{L}}{\partial E} & =\lambda_{1}-\lambda_{2}=0 \\
\frac{\partial \mathcal{L}}{\partial C} & =-R(\tilde{x})-\lambda_{4}(1-\gamma) \delta^{\prime}(\tilde{C})-\frac{\lambda_{5}}{\left(p_{H}-p_{L}\right)}=0 .
\end{aligned}
$$

Straightforward manipulation of these conditions delivers

$$
\begin{aligned}
& \lambda_{1}=\lambda_{2}=\beta>0 \\
& \lambda_{4}=\frac{p_{H}}{p_{H}-p_{L}} \lambda_{2} R(\tilde{x})=\frac{p_{H}}{p_{H}-p_{L}} \beta R(\tilde{x})>0 \\
& \lambda_{5}=(\beta-1) p_{H} R(\tilde{x})>0,
\end{aligned}
$$

from which we conclude that all constraints bind, as claimed in the main text.

The fact that $\lambda_{5}>1$ immediately implies that constraint $(\mathrm{v})$ binds and we have $\tilde{\phi}_{I}=$ $\tilde{C} /\left(p_{H}-p_{L}\right)$, as indicated in equation (2). Next, plugging the values of the multipliers in (A3) yields

$$
-\delta^{\prime}(\tilde{C})=\frac{\beta p_{H}-p_{L}}{(1-\gamma) \beta p_{H}}
$$

as claimed in equation (3) in the main text. Next, plugging the multipliers and $\tilde{\phi}_{I}$ into (A2) yields

$$
R^{\prime}(\tilde{x})=\frac{1}{p_{H}\left(1-\frac{(1-\gamma) \delta(\tilde{C})}{p_{H}-p_{L}}-\left(\frac{\beta p_{H}-p_{L}}{p_{H}-p_{L}}\right) \frac{\tilde{C}}{\beta p_{H}}\right)},
$$

which corresponds to equation (4) in the main text. 
Setting the constraints to equality, we can also compute the total payoff obtained by the inventor:

$$
\tilde{\Pi}_{I}=W \beta+\beta\left(\frac{R(\tilde{x})}{R^{\prime}(\tilde{x})}-\tilde{x}\right) .
$$

This expression can be used to analyze when it is optimal for the inventor to implement good behavior. To do so, consider the optimal contract that implements bad behavior. It is clear that in this case the inventor has no incentive to exert monitoring effort. It is also immediate that even when the entrepreneur does not obtain any share of the cash flows, her participation constraint will be satisfied, and thus we have that $\tilde{\phi}_{I}^{L}+\tilde{\phi}_{E}^{L}=1$. The program defining the optimal contract can then be written as

$$
\begin{array}{cl}
\max _{F, \phi_{I}, x, E} & \Pi_{I}=\phi_{I} p_{L} R(x)+(W-F) \beta \\
\text { s.t. } & x \leq E+F \\
& p_{L}\left(1-\phi_{I}\right) R(x) \geq E \\
& \phi_{I} \geq 0
\end{array}
$$

Following the same steps as before, we find that all three constraints will bind, and hence $\tilde{C}^{L}=\tilde{\phi}_{I}^{L}=0$. Furthermore, the optimal level of investment is given by

$$
p_{L} R^{\prime}\left(\tilde{x}^{L}\right)=1
$$

while the overall payoff obtained by the inventor equals:

$$
\tilde{\Pi}^{L}=\beta W+\beta\left(\frac{R\left(\tilde{x}^{L}\right)}{R^{\prime}\left(\tilde{x}^{L}\right)}-\tilde{x}^{L}\right) .
$$

Comparing equations (A4) and (A5) we see that $\tilde{\Pi}_{I}>\tilde{\Pi}^{L}$ if and only if

$$
\frac{R(\tilde{x})}{R^{\prime}(\tilde{x})}-\tilde{x}>\frac{R\left(\tilde{x}^{L}\right)}{R^{\prime}\left(\tilde{x}^{L}\right)}-\tilde{x}^{L} .
$$

But since $\frac{R(x)}{R^{\prime}(x)}-x$ is strictly increasing in $x$ whenever $R^{\prime \prime}(x)<0$, we can conclude that good behavior will be implemented whenever

$$
\tilde{x}>\tilde{x}^{L} .
$$

Note also that $\tilde{x}$ is increasing in $\gamma$ (this is formally proved in Appendix A.3), while $\tilde{x}^{L}$ is independent of $\gamma$. Furthermore, when $\gamma \rightarrow 1$, it is necessarily the case that $\tilde{x}>\tilde{x}^{L}$. Hence, there exists a threshold $\gamma$ over which it is optimal to implement good behavior. 


\section{A.3 Proofs of Comparative Static Results}

The comparative statics in Lemma 1 simply follow from the fact that the right-hand side of equation (3) is increasing in $\gamma$ and $\beta$, while the left-hand is decreasing in $\tilde{C}$ (given the convexity of $\delta(\cdot))$. $\tilde{C}$.

The statements of Proposition 1 directly follow from Lemma 1 because $\tilde{\phi}_{I}$ is proportional to

Consider next the comparative statics in Proposition 2. For that purpose, let

$$
F(\gamma, \beta, \tilde{C}(\gamma, \beta))=\frac{(1-\gamma) \delta(\tilde{C})}{p_{H}-p_{L}}+\left(\frac{\beta p_{H}-p_{L}}{p_{H}-p_{L}}\right) \frac{\tilde{C}}{\beta p_{H}}
$$

so that

$$
p_{H} R^{\prime}(\tilde{x})[1-F(\gamma, \beta, \tilde{C}(\gamma, \beta))]=1 .
$$

Using equation (3), we can establish that:

$$
\begin{aligned}
\frac{d F(\cdot)}{d \gamma} & =-\frac{\delta(\tilde{C})}{p_{H}-p_{L}}+\frac{(1-\gamma) \delta^{\prime}(\tilde{C})}{p_{H}-p_{L}} \frac{d \tilde{C}}{d \gamma}+\left(\frac{\beta p_{H}-p_{L}}{p_{H}-p_{L}}\right) \frac{1}{\beta p_{H}} \frac{d \tilde{C}}{d \gamma}=-\frac{\delta(\tilde{C})}{p_{H}-p_{L}}<0 \\
\frac{d F(\cdot)}{d \beta} & =\frac{(1-\gamma) \delta^{\prime}(\tilde{C})}{p_{H}-p_{L}} \frac{d \tilde{C}}{d \beta}+\left(\frac{\beta p_{H}-p_{L}}{p_{H}-p_{L}}\right) \frac{1}{\beta p_{H}} \frac{d \tilde{C}}{d \beta}+\frac{p_{L} \tilde{C}}{\left(p_{H}-p_{L}\right) \beta^{2} p_{H}}=\frac{p_{L} \tilde{C}}{\left(p_{H}-p_{L}\right) \beta^{2} p_{H}}>0 .
\end{aligned}
$$

From inspection of (4) and the concavity of $R(\cdot)$, it is then clear that $\tilde{x}$ is increasing in $\gamma$ and decreasing in $\beta$.

Finally, the statements in Proposition 3 follow from the discussion in the main text and the fact that $R(\tilde{x}) / \tilde{x}$ is decreasing in $\tilde{x}$, and thus decreasing in $\gamma$ and increasing in $\beta$.

\section{A.4 Generalizations}

In this Appendix, we provide more details on the generalizations outlined in section 2.3.

Consider first the case in which the entrepreneur's private benefit and the inventor's private cost of monitoring are proportional to $x$ rather than to $R(x)$. Following the same steps as in the formulation in the main text, we find that the optimal $\hat{C}$ and $\hat{x}$ are now given by

$$
-\delta^{\prime}(\hat{C})=\frac{\beta p_{H}-p_{L}}{\beta p_{H}(1-\gamma)}
$$

and

$$
p_{H} R^{\prime}(\hat{x})=1+\frac{\left(\beta p_{H}-p_{L}\right) \hat{C}}{\beta\left(p_{H}-p_{L}\right)}+\frac{p_{H}(1-\gamma) \delta(\hat{C})}{p_{H}-p_{L}} .
$$

Straightforward differentiation indicates that both $\hat{C}$ and $\hat{x}$ continue to be decreasing in $\gamma$, as 
in our paper. Next note that we can use equation (A6) to write

$$
\begin{aligned}
\hat{\phi}_{I} & =\frac{\hat{C}}{\left(p_{H}-p_{L}\right)} \frac{\hat{x}}{R(\hat{x})}=\frac{p_{H} \hat{C}}{\left(p_{H}-p_{L}\right)} \frac{\hat{x} R^{\prime}(\hat{x})}{R(\hat{x})} \frac{\hat{C}}{p_{H} R^{\prime}(\hat{x})} \\
& =\frac{p_{H}}{\left(p_{H}-p_{L}\right)} \frac{\hat{x} R^{\prime}(\hat{x})}{R(\hat{x})}\left[\frac{1}{\hat{C}}+\frac{\left(\beta p_{H}-p_{L}\right)}{\beta\left(p_{H}-p_{L}\right)}+\frac{p_{H}(1-\gamma) \delta(\hat{C})}{\left(p_{H}-p_{L}\right) \hat{C}}\right]^{-1} .
\end{aligned}
$$

It is straightforward to see that the last term continues to be an increasing function of $\hat{C}$ and is thus decreasing in $\gamma$. This implies that the only way that $\hat{\phi}_{I}$ could be increasing in $\gamma$ would be if the elasticity of revenue to output - that is $\alpha(\hat{x}) \equiv \hat{x} R^{\prime}(\hat{x}) / R(\hat{x})$ - was sufficiently increasing in $\hat{x}$. For a constant-elasticity function, $R(x)=A x^{\alpha}$, we have $\alpha(\hat{x})=\alpha$ for all $\hat{x}$ and thus $\hat{\phi}_{I}$ continues to be decreasing in $\gamma$ for any level of concavity of the $R(x)$ function. Remember that the revenue function will be isoelastic whenever the firm faces a demand with constant price-elasticity. If the firm where to face a linear demand function, then we would have that $\alpha(\hat{x})$ would be decreasing in $\hat{x}$, hence reinforcing the result that $\hat{\phi}_{I}$ is decreasing in $\gamma$.

We next consider the case in which (local) external investors can also serve a monitoring role. In particular, if external investors exert an unverifiable effort cost $M R(x)$, the private benefit is now:

$$
B(C, M ; \gamma)=(1-\gamma)(\delta(C)+\mu(M))
$$

with $\mu(\cdot)$ satisfying similar the same properties as $\delta(\cdot)$ above, namely, $\mu^{\prime}(M)<0, \mu^{\prime \prime}(M)>$ $0, \mu(0)=\bar{\mu}, \lim _{M \rightarrow \infty} \mu(M)=0, \lim _{M \rightarrow 0} \mu^{\prime}(M)=-\infty$, and $\lim _{M \rightarrow \infty} \mu^{\prime}(M)=0$. Because local monitoring is not verifiable, the program that determines the optimal contract will need to include a new incentive compatibility constraint for external investors. In particular, an optimal contract that induces the entrepreneur to behave is now given by the tuple $\left\{\hat{F}, \hat{\phi}_{I}, \hat{x}, \hat{\phi}_{E}, \hat{E}, \hat{C}, \hat{M}\right\}$ that solves a program analogous to (P1) but with constraints (ii) and (iv) now given by :

$$
\begin{aligned}
& p_{H} \phi_{E} R(x)-M R(x) \geq E \\
& \left(p_{H}-p_{L}\right)\left(1-\phi_{E}-\phi_{I}\right) \geq(1-\gamma)(\delta(C)+\mu(M))
\end{aligned}
$$

and with the additional constraint

$$
\phi_{E} \geq M /\left(p_{H}-p_{L}\right) \quad(\mathrm{vi})
$$

Manipulating the first-order conditions of this new program, we obtain that:

$$
\lambda_{5}=(\beta-1) p_{H} R^{\prime}(\hat{x})+\lambda_{6}
$$

which immediately implies that constraint (v) continues to bind even in the case with local monitoring. Consequently, inventor (or parent firm) equity shares continues to move proportionately with the amount of monitoring undertaken by the inventor. 
Furthermore, provided that the level of investor protection is sufficiently high, the analysis in the main text goes through essentially unaltered. The reason for this is that in such a case constraint (vi) is not binding $\left(\lambda_{6}=0\right)$ and we obtain that $\hat{C}$ and $\hat{M}$ being determined by:

$$
-\delta^{\prime}(\hat{C})=\frac{\beta p_{H}-p_{L}}{(1-\gamma) \beta p_{H}}
$$

which is identical to (3), and

$$
-\mu^{\prime}(\hat{M})=\frac{\left(p_{H}-p_{L}\right)}{(1-\gamma) p_{H}}
$$

From the convexity of the monitoring functions, we thus obtain that both $\hat{C}$ and $\hat{M}$ are decreasing functions of $\gamma$. Furthermore, manipulating the first-order conditions it can also be easily shown that (i) the investment levels (and thus) sale revenue continue to be increasing in $\gamma$, and (ii) the ratio $\hat{F} / \widehat{x}$ is still increasing in $\gamma$ provided that $\alpha(\hat{x})$ does not increase in $\hat{x}$ too quickly, just as in the main text (details available upon request).

Note that equations (A7) and (A8) also imply that $-\delta^{\prime}(\hat{C})>-\mu^{\prime}(\hat{M})$, and if the functions $\delta(\cdot)$ and $\mu(\cdot)$ are sufficiently similar we will have $\hat{M}>\hat{C}$. Intuitively, a disproportionate amount of local monitoring may be optimal because it is "cheaper", since external investors have a lower shadow cost of getting remunerated through equity shares. Still, as long as the equilibrium level of $\hat{M}$ is sufficiently low (or $\gamma$ is sufficiently high), the above analysis suggests that inventor equity shares comoves with investor protection in the same manner than in our simpler model with only inventor monitoring.

For low enough values of $\gamma$, however, the above optimal contract leads to $\hat{M}>\left(p_{H}-p_{L}\right) \widehat{\phi}_{E}$, which violates constraint (vi). In such a case, we have $\lambda_{6}>0$. Manipulating the first-order conditions, one can show that $\hat{C}$ and $\hat{M}$ are implicitly defined by the system:

$$
\begin{aligned}
& \frac{1+(1-\gamma) \mu^{\prime}(\hat{M})}{1+(1-\gamma) \delta^{\prime}(\hat{C})}=\beta \\
& p_{H}-p_{L}-\hat{C}-\hat{M}=(1-\gamma)(\delta(\hat{C})+\mu(\hat{M})) .
\end{aligned}
$$

Unfortunately, without imposing particular functional forms for the functions $\delta(\cdot)$ and $\mu(\cdot)$, it becomes impossible to characterize how $\hat{C}$ (and thus $\hat{\phi}_{I}$ ) vary with $\gamma$. 


\section{References}

Acemoglu, Daron, Simon Johnson and Todd Mitton (2005), "Determinants of Vertical Integration: Finance Contracts and Regulation," NBER Working Paper No. 11424.

Aguiar, Mark and Gita Gopinath (2005), "Fire-Sale FDI and Liquidity Crises," Review of Economics and Statistics, 87:3, pp. 439-452.

Albuquerque, Rui (2003), "The Composition of International Capital Flows: Risk Sharing Through Foreign Direct Investment," Journal of International Economics, Vol. 61(2), pp. 353-383.

Antràs, Pol (2003), "Firms, Contracts, and Trade Structure," Quarterly Journal of Economics, 118:4, pp. 1375-1418.

Antràs, Pol (2005), "Incomplete Contracts and the Product Cycle," American Economic Review, 95:4, pp. 1054-1073.

Antràs, Pol and Elhanan Helpman (2004), "Global Sourcing," Journal of Political Economy 112:3, pp. 552-580.

Antràs, Pol, Mihir A. Desai and C. Fritz Foley (2007), "Multinational Firms, FDI Flows and Imperfect Capital Markets," NBER Working Paper No. 12855.

Baker, Malcolm, C. Fritz Foley and Jeffrey Wurgler (forthcoming), "Multinationals as Arbitrageurs? The Effects of Stock Market Valuations on Foreign Direct Investment," Review of Financial Studies.

Barro, Robert J. and Jong-Wha Lee (2000), "International Data on Educational Attainment: Updates and Implications," CID Working Paper No. 42.

Beck, Thorsten, Asli Demirgüç-Kunt and Ross Levine (1999), "A New Database on Financial Development and Structure," Policy Research Working Paper No. 2146, Washington DC: World Bank.

Bertaut, Carol, William L. Griever and Ralph W. Tryon (2006), "Understanding U.S. CrossBorder Securities Data," Federal Reserve Bulletin, vol. 92 (May 2006), pp. A59-A75.

Blonigen, Bruce A. (1997), "Firm-Specific Assets and the Link Between Exchange Rates and Foreign Direct Investment" American Economic Review, 87:3, pp. 447-465.

Boyd, John H. and Bruce D. Smith (1997), "Capital Market Imperfections, International Credit Markets and Nonconvergence," Journal of Economic Theory, 73:2 335-364.

Brainard, S. Lael (1997), "An Empirical Assessment of the Proximity-Concentration Trade-off Between Multinational Sales and Trade," American Economic Review, 87:4, pp. 520-544.

Caves, Richard E. (1996), Multinational Enterprise and Economic Analysis, Second Edition, Cambridge University Press. 
Desai, Mihir A., C. Fritz Foley and Kristin J. Forbes (forthcoming), "Financial Constraints and Growth: Multinational and Local Firm Responses to Currency Depreciations," Review of Financial Studies.

Desai, Mihir A., C. Fritz Foley and James R. Hines Jr. (2002), "Dividend Policy Inside the Firm," forthcoming in Financial Management.

Desai, Mihir A., C. Fritz Foley and James R. Hines Jr. (2004), "The Costs of Shared Ownership: Evidence from International Joint Ventures," Journal of Financial Economics, 73:2, pp. 323-374.

Desai, Mihir A., C. Fritz Foley and James R. Hines Jr. (2004b), "A Multinational Perspective on Capital Structure Choice and Internal Capital Markets," Journal of Finance, 59:6, pp. 2451-2488.

Djankov, Simeon, Caralee McLiesh, and Andrei Shleifer (2007), "Private Credit in 129 Countries," Journal of Financial Economics, 84:2, pp. 299-329.

Ethier, Wilfred J. and James R. Markusen (1996), "Multinational Firms, Technology Diffusion and Trade," Journal of International Economics, 41:1, pp. 1-28.

Feenstra, Robert and Gordon Hanson (2005), "Ownership and Control in Outsourcing to China: Estimating the Property-Rights Theory of the Firm," Quarterly Journal of Economics, 120:2, pp. 729-761.

Froot, Kenneth A., and Jeremy C. Stein (1991), "Exchange Rates and Foreign Direct Investment: An Imperfect Capital Markets Approach," Quarterly Journal of Economics, 106:4, pp. 1191-1217.

Gertler, Mark and Kenneth S. Rogoff (1990), "North-South Lending and Endogenous Domestic Capital Market Inefficiencies," Journal of Monetary Economics, 26:2, pp. 245-266.

Ginarte, Jaun Carlos, and Walter Park (1997), "Determinants of Patent Rights: A CrossNational Study," Research Policy, 26:3, pp. 283-301.

Grossman, Gene M., and Elhanan Helpman, (2004) "Managerial Incentives and the International Organization of Production," Journal of International Economics, 63:2, pp. 237262.

Harris, Milton and Arthur Raviv (1991), "The Theory of Capital Structure," Journal of Finance, 46:1, pp. 297-355.

Helpman, Elhanan (1984), "A Simple Theory of International Trade with Multinational Corporations", Journal of Political Economy, 92:3, pp. 451-471.

Helpman, Elhanan, Marc J. Melitz, and Stephen R. Yeaple (2004), "Exports versus FDI with Heterogeneous Firms," American Economic Review, 94:1, pp. 300-316. 
Holmstrom, Bengt and Jean Tirole (1997), "Financial Intermediation, Loanable Funds, and the Real Sector," Quarterly Journal of Economics, 112:3, pp. 663-691.

King, Robert G., Ross Levine (1993), "Finance and Growth: Schumpeter Might be Right," Quarterly Journal of Economics, 108:3, pp. 717-738.

Klein, Michael W., Joe Peek, and Eric Rosengren (2002), "Troubled Banks, Impaired Foreign Direct Investment: The Role of Relative Access to Credit," American Economic Review, 92:3, pp. 664-682.

Klein, Michael W., and Eric Rosengren (1994), "The Real Exchange Rate and Foreign Direct Investment in the United States," Journal of International Economics, 36:3-4, pp. 373389.

Kraay, Aart, Norman Loayza, Luis Servén, and Jaume Ventura (2005), "Country Portfolios," Journal of the European Economic Association, 3:4, pp. 914-945.

La Porta, Rafael, Florencio Lopez-de-Silanes, Andrei Shleifer, and Robert W. Vishny (1998), "Law and Finance," Journal of Political Economy, 106:6, pp. 1113-1155.

La Porta, Rafael, Florencio Lopez-de-Silanes, Andrei Shleifer, and Robert W. Vishny (1997), "Legal Determinants of External Finance," Journal of Finance, 52:3, pp. 1131-1150.

Levine, Ross and Sara Zervos (1998), "Stock Markets, Banks and Economic Growth," American Economic Review, 88:3, pp. 537-558.

Lucas, Robert (1990), "Why Doesn't Capital Flow from Rich to Poor Countries?" American Economic Review, 80:3, pp. 92-96.

Marin, Dalia and Monika Schnitzer (2004), "Global Versus Local: The Financing of Foreign Direct Investment," Working paper, University of Munich.

Markusen, James R. (1984), "Multinationals, Multi-Plant Economies, and the Gains from Trade," Journal of International Economics, 16:3-4, pp. 205-226.

Markusen, James R. and Anthony J. Venables (2000), "The Theory of Endowment, Intraindustry and Multi-national Trade," Journal of International Economics, 52:2, pp. 209234.

Markusen, James R. (2002), Multinational Firms and the Theory of International Trade, Cambridge, MA: MIT Press.

Misawa, Mitsuru (2005), "Tokyo Disneyland: Licensing vs. Joint Venture," Asia Case Research Centre, The University of Hong Kong, Case HKU420.

Rajan, Raghuram G., and Luigi Zingales (1995), "What Do We Know About Capital Structure? Some Evidence from International Data," Journal of Finance, 50:5, pp. 1421-1460. 
Rajan, Raghuram G., and Luigi Zingales (1998), "Financial Dependence and Growth," American Economic Review 88:3, 559-586.

Reinhart, Carmen M. and Kenneth S. Rogoff (2004), "Serial Default and the "Paradox" of Rich to Poor Capital Flows," American Economic Review, 94:2, pp. 52-58.

Shatz, Howard J. (2000), "The Location of U.S. Multinational Affiliates," Ph.D. dissertation, Harvard University.

Shleifer, Andrei and Daniel Wolfenzon (2002), "Investor Protection and Equity Markets," Journal of Financial Economics, 66:1, pp. 3-27.

Tirole, Jean (2006), The Theory of Corporate Finance, Princeton: Princeton University Press.

Wurgler, Jeffrey (2000), "Financial Markets and the Allocation of Capital," Journal of Financial Economics 58:1-2, 187-214.

Yeaple, Stephen (2003), "The Role of Skill Endowments in the Structure of U.S. Outward FDI," Review of Economics and Statistics, 85:3, pp. 726-734. 


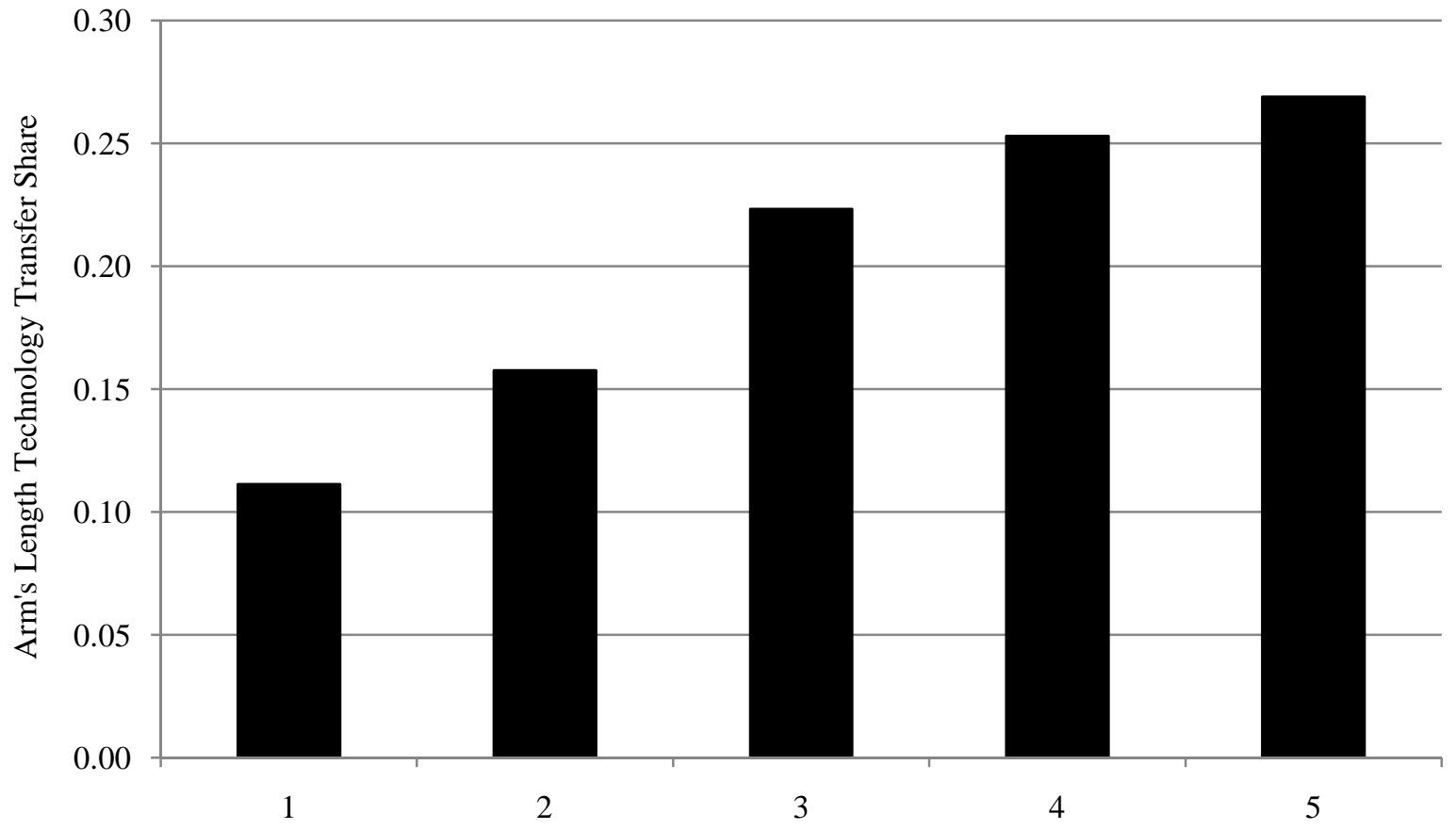

Private Credit Quintile

Figure I

Arm's Length Technology Transfer Versus Direct Investment

Note: Arm's Length Technology Transfer Share is the ratio of the number of firms that receive a royalty from an unaffiliated foreign person to the sum of the number of such firms and those firms that have an affiliate in a particular country and year. These shares are averaged by quintiles of private credit. Private credit varies by year and is the ratio of private credit lent by deposit money banks to GDP, as provided in Beck et. al. (1999). Higher number quintiles relate to higher values of private credit. 


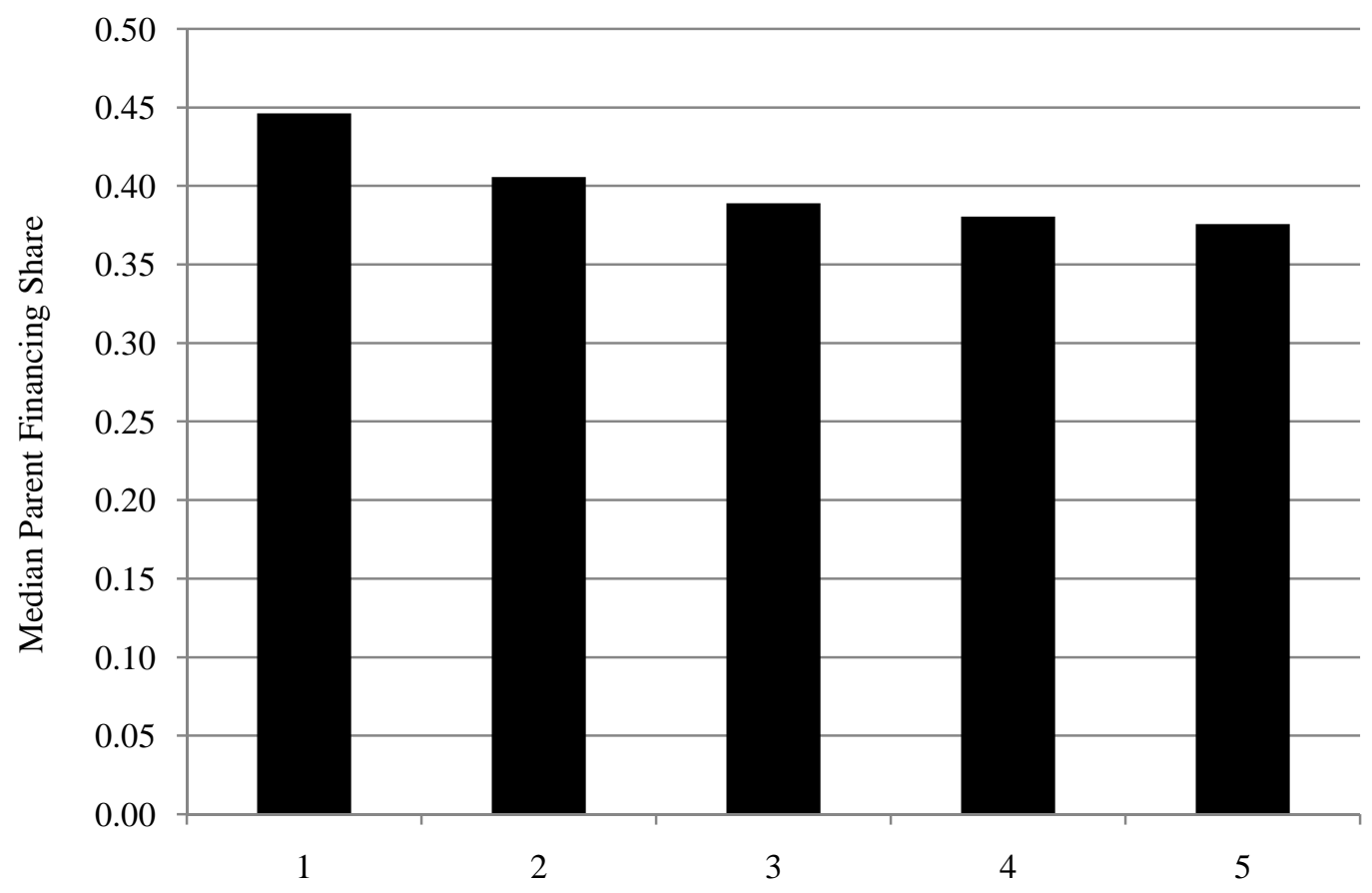

Private Credit Quintile

Figure II

Parent Financing of Affiliate Assets

Note: Parent financing share is the ratio of the sum of net borrowing from the parent and parent equity provisions to affiliate assets. The bars display medians of the country level average shares for each quintile of private credit. Private credit is the ratio of private credit lent by deposit money banks to GDP, as provided in Beck et. al. (1999). Higher number quintiles relate to higher values of private credit. 


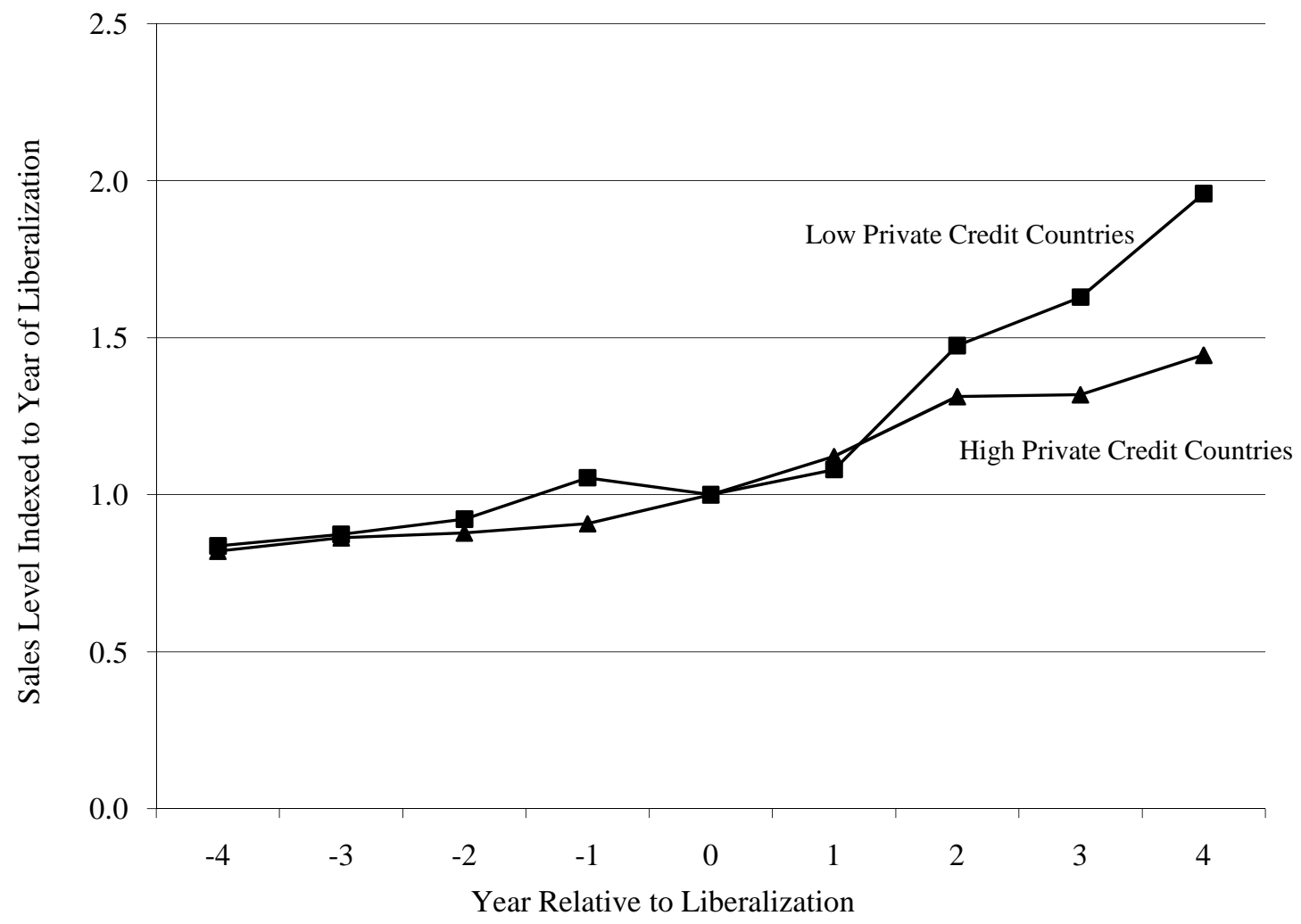

Figure III

Liberalizations and Multinational Firm Growth

Note: The two lines correspond to averages of an index computed at the country level as the ratio of aggregate affiliate sales in a given year to the level of sales in the year of the liberalization. Countries are split into two samples at the median level of private credit. Private credit is the ratio of private credit lent by deposit money banks to GDP, as provided in Beck et. al. (1999). 
Table I

Descriptive Statistics

Standard

$\underline{\text { Mean }}$

Deviation

Panel A: Benchmark Year Data for Tables II-V

Multinational Firm Variables

Arm's Length Technology Transfer Dummy

0.2552

0.4360

Share of Affiliate Assets Financed by Parent

0.4146

0.3267

Share of Affiliate Equity Owned by Parent

0.8991

0.2195

Log of Affiliate Sales

9.9024

1.7218

Log of Affiliate Employment

4.7601

1.6060

Affiliate Net PPE/Assets

0.2355

0.2264

Log of Parent R\&D

9.0580

4.3927

Country Variables

Creditor Rights

2.1415

1.2100

Private Credit

0.7536

0.3891

FDI Ownership Restrictions

0.2247

0.4174

Workforce Schooling

8.1385

2.1739

Log of GDP

26.8002

1.4252

Log of GDP per Capita

9.3995

1.1019

Corporate Tax Rate

0.3488

0.1060

Patent Protections

3.2287

0.8480

Property Rights

Rule of Law

Risk of Expropriation

Panel B: Annual Data for Table IV

Log of Affiliate Sales

10.1285

2.1426

Log of Aggregate Affiliate Sales

15.7572

1.7018

Notes: Panel A provides descriptive statistics for data drawn from the benchmark year survey and used in the analysis presented in Tables II-V. Arm's Length Technology Transfer Dummy is defined for country-year pairs in which a parent has an affiliate or from which a parent receives a royalty payment from an unaffiliated foreign person. This dummy is equal to one if the parent receives a royalty payment from an unaffiliated foreign person, and it is otherwise equal to zero. Share of Affiliate Assets Financed by Parents is the ratio of parent provided equity and net parent lending to total affiliate assets. Share of Affiliate Equity Ownership is the equity ownership of the multinational parent. Affiliate Net PPE/Assets is the ratio of affiliate net property plant and equipment to affiliate assets. Creditor Rights is an index of the strength of creditor rights developed in Djankov, McLiesh, and Shleifer (2007); higher levels of the measure indicate stronger legal protections. Private Credit is the ratio of private credit lent by deposit money banks to GDP, as provided in Beck et. al. (1999). FDI Ownership Restrictions is a dummy equal to zero if two measures of restrictions on foreign ownership as measured by Shatz (2000) are above 3 on a scale of 1 to 5 and one otherwise. Workforce Schooling is the average schooling years in the population over 25 years old provided in Barro and Lee (2000). Corporate Tax Rate is the median effective tax rate paid by affiliates in a particular country and year. Patent Protections is an index of the strength of patent rights provided in Ginarte and Park (1997). Property Rights is an index of the strength of property rights drawn from the 1996 Index of Economic Freedom. Rule of Law is an assessment of the strength and impartiality of a country's overall legal system drawn from the International Country Risk Guide. Risk of Expropriation is an index of the risk of outright confiscation or forced nationalization of private enterprise, and it is also drawn from the International Country Risk Guide; higher values of this index reflect lower risks. Panel B provides descriptive statistics for annual data covering the 1982-1999 period that are used in the analysis presented in Table IV. Log of Aggregate Affiliate Sales is the log of affiliate sales summed across affiliates in a particular country and year. 
Table II

Arm's Length Technology Transfer Versus Direct Investment

\begin{tabular}{|c|c|c|c|c|c|c|}
\hline \multirow[t]{2}{*}{ Dependent Variable: } & \multicolumn{6}{|c|}{ Arm's Length Technology Transfer Dummy } \\
\hline & (1) & $(2)$ & (3) & (4) & (5) & (6) \\
\hline Creditor Rights & $\begin{array}{r}0.0086 \\
(0.0022)\end{array}$ & $\begin{array}{r}0.0131 \\
(0.0026)\end{array}$ & $\begin{array}{r}0.0023 \\
(0.0039)\end{array}$ & & & \\
\hline $\begin{array}{l}\text { Creditor Rights*Log of Parent } \\
\text { R\&D }\end{array}$ & & & $\begin{array}{r}0.0016 \\
(0.0005)\end{array}$ & & & \\
\hline Private Credit & & & & $\begin{array}{r}0.0273 \\
(0.0129)\end{array}$ & $\begin{array}{r}0.0295 \\
(0.0147)\end{array}$ & $\begin{array}{r}-0.0606 \\
(0.0133)\end{array}$ \\
\hline $\begin{array}{l}\text { Private Credit*Log of Parent } \\
\text { R\&D }\end{array}$ & & & & & & $\begin{array}{r}0.0117 \\
(0.0020)\end{array}$ \\
\hline FDI Ownership Restrictions & $\begin{array}{r}0.0098 \\
(0.0089)\end{array}$ & $\begin{array}{r}0.0063 \\
(0.0085)\end{array}$ & $\begin{array}{r}0.0079 \\
(0.0094)\end{array}$ & $\begin{array}{r}-0.0001 \\
(0.0093)\end{array}$ & $\begin{array}{r}0.0017 \\
(0.0087)\end{array}$ & $\begin{array}{r}0.0020 \\
(0.0097)\end{array}$ \\
\hline Workforce Schooling & $\begin{array}{r}0.0069 \\
(0.0019)\end{array}$ & $\begin{array}{r}0.0122 \\
(0.0018)\end{array}$ & $\begin{array}{r}0.0134 \\
(0.0020)\end{array}$ & $\begin{array}{r}0.0066 \\
(0.0025)\end{array}$ & $\begin{array}{r}0.0097 \\
(0.0021)\end{array}$ & $\begin{array}{r}0.0103 \\
(0.0024)\end{array}$ \\
\hline Log of GDP & $\begin{array}{r}0.0238 \\
(0.0032)\end{array}$ & $\begin{array}{r}0.0239 \\
(0.0033)\end{array}$ & $\begin{array}{r}0.0268 \\
(0.0038)\end{array}$ & $\begin{array}{r}0.0212 \\
(0.0031)\end{array}$ & $\begin{array}{r}0.0216 \\
(0.0035)\end{array}$ & $\begin{array}{r}0.0243 \\
(0.0039)\end{array}$ \\
\hline Log of GDP per Capita & $\begin{array}{r}-0.0148 \\
(0.0039)\end{array}$ & $\begin{array}{r}-0.0129 \\
(0.0058)\end{array}$ & $\begin{array}{r}-0.0144 \\
(0.0066)\end{array}$ & $\begin{array}{r}-0.0179 \\
(0.0047)\end{array}$ & $\begin{array}{r}-0.0182 \\
(0.0067)\end{array}$ & $\begin{array}{r}-0.0223 \\
(0.0077)\end{array}$ \\
\hline Corporate Tax Rate & $\begin{array}{r}0.1239 \\
(0.0435)\end{array}$ & $\begin{array}{r}0.1583 \\
(0.0413)\end{array}$ & $\begin{array}{r}0.1777 \\
(0.0453)\end{array}$ & $\begin{array}{r}0.1367 \\
(0.0434)\end{array}$ & $\begin{array}{r}0.1363 \\
(0.0393)\end{array}$ & $\begin{array}{r}0.1588 \\
(0.0438)\end{array}$ \\
\hline Patent Protections & & $\begin{array}{r}0.0124 \\
(0.0046)\end{array}$ & $\begin{array}{r}0.0127 \\
(0.0052)\end{array}$ & & $\begin{array}{r}0.0155 \\
(0.0057)\end{array}$ & $\begin{array}{r}0.0158 \\
(0.0066)\end{array}$ \\
\hline Property Rights & & $\begin{array}{r}-0.0227 \\
(0.0061)\end{array}$ & $\begin{array}{r}-0.0254 \\
(0.0067)\end{array}$ & & $\begin{array}{r}-0.0095 \\
(0.0057)\end{array}$ & $\begin{array}{r}-0.0086 \\
(0.0066)\end{array}$ \\
\hline Rule of Law & & $\begin{array}{r}-0.0013 \\
(0.0039)\end{array}$ & $\begin{array}{r}-0.0022 \\
(0.0043)\end{array}$ & & $\begin{array}{r}-0.0025 \\
(0.0043)\end{array}$ & $\begin{array}{r}-0.0040 \\
(0.0046)\end{array}$ \\
\hline Risk of Expropriation & & $\begin{array}{r}-0.0076 \\
(0.0044)\end{array}$ & $\begin{array}{r}-0.0080 \\
(0.0049)\end{array}$ & & $\begin{array}{c}-0.0082 \\
(0.0050)\end{array}$ & $\begin{array}{r}-0.0080 \\
(0.0055)\end{array}$ \\
\hline Constant & $\begin{array}{r}-0.3780 \\
(0.0840)\end{array}$ & $\begin{array}{c}-0.3569 \\
(0.0822)\end{array}$ & $\begin{array}{r}-0.5162 \\
(0.0979)\end{array}$ & $\begin{array}{c}-0.2839 \\
(0.0807)\end{array}$ & $\begin{array}{r}-0.2638 \\
(0.0843)\end{array}$ & $\begin{array}{r}-0.3923 \\
(0.0968)\end{array}$ \\
\hline Parent-Year Fixed Effects? & $\mathrm{Y}$ & $\mathrm{Y}$ & Y & $\mathrm{Y}$ & Y & $\mathrm{Y}$ \\
\hline $\begin{array}{l}\text { No. of Obs. } \\
\text { R-Squared }\end{array}$ & $\begin{array}{c}37,314 \\
0.7628\end{array}$ & $\begin{array}{c}36,029 \\
0.7645\end{array}$ & $\begin{array}{c}30,954 \\
0.6061\end{array}$ & $\begin{array}{c}34,583 \\
0.7598\end{array}$ & $\begin{array}{c}33,922 \\
0.7624\end{array}$ & $\begin{array}{r}29,238 \\
0.6105\end{array}$ \\
\hline $\begin{array}{l}\text { Notes: The dependent variable, the Arr } \\
\text { from which a parent receives a royalty } \\
\text { payment from an unaffiliated foreign } p \\
\text { in Djankov, McLiesh, and Shleifer (20 } \\
\text { lent by deposit money banks to GDP, a } \\
\text { restrictions on foreign ownership as me } \\
\text { schooling years in the population over } \\
\text { affiliates in a particular country and ye }\end{array}$ & $\begin{array}{l}\text { trom an una } \\
\text { ed it is otherw } \\
\text { ed in Beck et } \\
\text { oy Shatz (200 } \\
\text { old provided } \\
\text { th Protections }\end{array}$ & $\begin{array}{l}\text { ted forelgn pe } \\
\text { equal to zero. } \\
\text { easure indicate } \\
\text { (1999). FDI O } \\
\text { e above } 3 \text { on a } \\
\text { arro and Lee } \\
\text { n index of the }\end{array}$ & $\begin{array}{l}\text { litor Rights is } \\
\text { onger legal pro } \\
\text { rship Restrict } \\
\text { e of } 1 \text { to } 5 \text { an } \\
\text { ). Corporate } \\
\text { gth of patent }\end{array}$ & $\begin{array}{l}\text { qual to one if } \\
\text { dex of the str } \\
\text { ions. Private } \\
\text { is a dummy e } \\
\text { e otherwise. } \\
\text { Rate is the m } \\
\text { s provided in }\end{array}$ & $\begin{array}{l}\text { h a parent ha } \\
\text { arent receive } \\
\text { of creditor ri } \\
t \text { is the ratio o } \\
\text { to zero if two } \\
\text { force Schooli } \\
\text { effective tax } \\
\text { rte and Park ( }\end{array}$ & $\begin{array}{l}\text { ffiliate or } \\
\text { byalty } \\
\text { developed } \\
\text { vate credit } \\
\text { sures of } \\
\text { the average } \\
\text { paid by } \\
\text { ). Property }\end{array}$ \\
\hline $\begin{array}{l}\text { Rights is an index of the strength of pr } \\
\text { and impartiality of a country's overall } 1 \\
\text { outright confiscation or forced national } \\
\text { this index reflect lower risks. Each spe } \\
\text { errors that correct for clustering at the }\end{array}$ & $\begin{array}{l}\text { hts drawn fr } \\
\text { m drawn fro } \\
\text { private ente } \\
\text { is an OLS s }\end{array}$ & $\begin{array}{l}\text { e 1996Index } \\
\text { e Internationa } \\
\text { e, and it is als } \\
\text { fication that in } \\
\text { n parentheses. }\end{array}$ & $\begin{array}{l}\text { conomic Freec } \\
\text { untry Risk Gu } \\
\text { Iwn from the }\end{array}$ & $\begin{array}{l}\text { Rule of Lan } \\
\text { Risk of Expr } \\
\text { national Coun }\end{array}$ & $\begin{array}{l}\text { nassessment } \\
\text { tion is an inde } \\
\text { isk Guide; hi }\end{array}$ & $\begin{array}{l}\text { strength } \\
\text { the risk of } \\
\text { values of } \\
\text { ent standard }\end{array}$ \\
\hline
\end{tabular}


Table III

Parent Financing Decisions

\begin{tabular}{|c|c|c|c|c|c|c|}
\hline \multirow[t]{2}{*}{ Dependent Variable: } & \multicolumn{6}{|c|}{ Share of Affiliate Assets Financed by Parent } \\
\hline & (1) & $(2)$ & (3) & (4) & (5) & (6) \\
\hline Creditor Rights & $\begin{array}{r}-0.0166 \\
(0.0054)\end{array}$ & $\begin{array}{r}-0.0164 \\
(0.0051)\end{array}$ & $\begin{array}{r}-0.0080 \\
(0.0055)\end{array}$ & & & \\
\hline $\begin{array}{l}\text { Creditor Rights*Log of Parent } \\
\text { R\&D }\end{array}$ & & & $\begin{array}{r}-0.0010 \\
(0.0003)\end{array}$ & & & \\
\hline Private Credit & & & & $\begin{array}{r}-0.0632 \\
(0.0195)\end{array}$ & $\begin{array}{r}-0.0384 \\
(0.0215)\end{array}$ & $\begin{array}{r}-0.0084 \\
(0.0220)\end{array}$ \\
\hline $\begin{array}{l}\text { Private Credit*Log of Parent } \\
\text { R\&D }\end{array}$ & & & & & & $\begin{array}{r}-0.0031 \\
(0.0012)\end{array}$ \\
\hline FDI Ownership Restrictions & $\begin{array}{r}-0.0406 \\
(0.0146)\end{array}$ & $\begin{array}{r}-0.0426 \\
(0.0154)\end{array}$ & $\begin{array}{r}-0.0426 \\
(0.0155)\end{array}$ & $\begin{array}{r}-0.0323 \\
(0.0171)\end{array}$ & $\begin{array}{r}-0.0358 \\
(0.0160)\end{array}$ & $\begin{array}{r}-0.0358 \\
(0.0162)\end{array}$ \\
\hline Workforce Schooling & $\begin{array}{r}0.0200 \\
(0.0057)\end{array}$ & $\begin{array}{r}0.0110 \\
(0.0042)\end{array}$ & $\begin{array}{r}0.0114 \\
(0.0043)\end{array}$ & $\begin{array}{r}0.0199 \\
(0.0060)\end{array}$ & $\begin{array}{r}0.0151 \\
(0.0048)\end{array}$ & $\begin{array}{r}0.0157 \\
(0.0049)\end{array}$ \\
\hline Log of GDP & $\begin{array}{r}-0.0224 \\
(0.0055)\end{array}$ & $\begin{array}{r}-0.0180 \\
(0.0070)\end{array}$ & $\begin{array}{r}-0.0180 \\
(0.0071)\end{array}$ & $\begin{array}{l}-0.0157 \\
(0.0062)\end{array}$ & $\begin{array}{r}-0.0148 \\
(0.0084)\end{array}$ & $\begin{array}{r}-0.0148 \\
(0.0085)\end{array}$ \\
\hline Log of GDP per Capita & $\begin{array}{r}-0.0327 \\
(0.0112)\end{array}$ & $\begin{array}{r}-0.0066 \\
(0.0153)\end{array}$ & $\begin{array}{r}-0.0072 \\
(0.0154)\end{array}$ & $\begin{array}{r}-0.0285 \\
(0.0136)\end{array}$ & $\begin{array}{r}0.0027 \\
(0.0167)\end{array}$ & $\begin{array}{r}0.0030 \\
(0.0169)\end{array}$ \\
\hline Corporate Tax Rate & $\begin{array}{r}-0.1288 \\
(0.0776)\end{array}$ & $\begin{array}{r}-0.2135 \\
(0.0763)\end{array}$ & $\begin{array}{r}-0.2061 \\
(0.0764)\end{array}$ & $\begin{array}{r}-0.1135 \\
(0.0743)\end{array}$ & $\begin{array}{r}-0.1803 \\
(0.0742)\end{array}$ & $\begin{array}{r}-0.1731 \\
(0.0745)\end{array}$ \\
\hline Patent Protections & & $\begin{array}{r}-0.0392 \\
(0.0113)\end{array}$ & $\begin{array}{r}-0.0388 \\
(0.0114)\end{array}$ & & $\begin{array}{r}-0.0434 \\
(0.0119)\end{array}$ & $\begin{array}{r}-0.0436 \\
(0.0120)\end{array}$ \\
\hline Property Rights & & $\begin{array}{r}0.0112 \\
(0.0112)\end{array}$ & $\begin{array}{r}0.0110 \\
(0.0115)\end{array}$ & & $\begin{array}{r}-0.0096 \\
(0.0103)\end{array}$ & $\begin{array}{r}-0.0113 \\
(0.0106)\end{array}$ \\
\hline Rule of Law & & $\begin{array}{r}0.0059 \\
(0.0078)\end{array}$ & $\begin{array}{r}0.0062 \\
(0.0079)\end{array}$ & & $\begin{array}{r}0.0065 \\
(0.0080)\end{array}$ & $\begin{array}{r}0.0068 \\
(0.0080)\end{array}$ \\
\hline Risk of Expropriation & & $\begin{array}{r}0.0010 \\
(0.0090)\end{array}$ & $\begin{array}{r}0.0007 \\
(0.0091)\end{array}$ & & $\begin{array}{r}0.0009 \\
(0.0092)\end{array}$ & $\begin{array}{r}0.0003 \\
(0.0094)\end{array}$ \\
\hline Constant & $\begin{array}{r}1.2571 \\
(0.1083)\end{array}$ & $\begin{array}{r}0.9710 \\
(0.1420)\end{array}$ & $\begin{array}{r}0.9728 \\
(0.1435)\end{array}$ & $\begin{array}{r}1.0444 \\
(0.1479)\end{array}$ & $\begin{array}{r}0.8389 \\
(0.1868)\end{array}$ & $\begin{array}{r}0.8330 \\
(0.1906)\end{array}$ \\
\hline $\begin{array}{l}\text { Parent-Year Fixed Effects? } \\
\text { Affiliate Controls? }\end{array}$ & $\begin{array}{l}\mathrm{Y} \\
\mathrm{N}\end{array}$ & $\begin{array}{l}\mathrm{Y} \\
\mathrm{Y}\end{array}$ & $\begin{array}{l}\mathrm{Y} \\
\mathrm{Y}\end{array}$ & $\begin{array}{l}\mathrm{Y} \\
\mathrm{N}\end{array}$ & $\begin{array}{l}\mathrm{Y} \\
\mathrm{Y}\end{array}$ & $\begin{array}{l}\mathrm{Y} \\
\mathrm{Y}\end{array}$ \\
\hline $\begin{array}{l}\text { No. of Obs. } \\
\text { R-Sauared }\end{array}$ & 51,060 & 41,232 & 40,297 & 48,183 & 38,911 & $\begin{array}{r}38,016 \\
0,3134\end{array}$ \\
\hline $\begin{array}{l}\text { R-Squared } \\
\text { Notes: The dependent variable is the } \\
\text { creditor rights developed in Djankov, } \\
\text { the ratio of private credit lent by depos } \\
\text { zero if two measures of restrictions on } \\
\text { Schooling is the average schooling yea } \\
\text { effective tax rate paid by affiliates in a } \\
\text { and Park (1997). Property Rights is ar } \\
\text { assessment of the strength and imparti } \\
\text { is an index of the risk of outright confi } \\
\text { Guide; higher values of this index refl } \\
\text { controls, the specifications presented i } \\
\text { PPE/assets. Affiliate Net PPE/Assets } \\
\text { errors that correct for clustering at the }\end{array}$ & $\begin{array}{l}0.3013 \\
\text { rent provided } \\
\text { and Shleifer } \\
\text { banks to GD } \\
\text { wnership as } \\
\text { population o } \\
\text { ir country anc } \\
\text { the strength } \\
\text { country's ove } \\
r \text { forced natio } \\
\text { risks. Each s } \\
\text { s 2, 3, 5, and } \\
\text { o of affiliate } \\
\text { vear level app }\end{array}$ & $\begin{array}{l}\text { ); higher le } \\
\text { provided in } \\
\text { ured by Shat } \\
\text { years old p. } \\
\text { - Patent Pro } \\
\text { operty rights } \\
\text { egal system } \\
\text { ation of priv } \\
\text { ication is an } \\
\text { lude the log } \\
\text { operty plant } \\
\text { parenthese }\end{array}$ & $\begin{array}{l}0.3071 \\
\text { ending to tota } \\
\mathrm{f} \text { the measure } \\
\text { et. al. (1999). } \\
\text { 00) are above } \\
\text { ed in Barro an } \\
\text { ns is an index } \\
\text { n from the } 19 \\
\text { from the Inte } \\
\text { terprise, and } \\
\text { specification } \\
\text { iliate sales, th } \\
\text { quipment to a }\end{array}$ & $\begin{array}{l}\frac{0.3076}{\text { ets. Creditor }} \\
\text { cate stronger l } \\
\text { I Ownership } \\
\text { a scale of } 1 \text { tc } \\
\text { e (2000). Cor } \\
\text { le strength of } \\
\text { dex of Econo } \\
\text { ional Country } \\
\text { lso drawn fro } \\
\text { includes parer } \\
\text { of affiliate er } \\
\text { ate assets. He }\end{array}$ & $\begin{array}{l}0.3167 \\
\text { ts is an index } \\
\text { protections. } \\
\text { ictions is a du } \\
\text { ad one otherw } \\
\text { te Tax Rate is } \\
\text { tt rights provi } \\
\text { rreedom. Ru } \\
\text { Guide. Risk } \\
\text { e Internationa } \\
\text { ar fixed effect } \\
\text { yment, and af } \\
\text { kedasticity co }\end{array}$ & $\begin{array}{l}\quad 0.3134 \\
\text { e strength of } \\
\text { te credit is } \\
\text { equal to } \\
\text { Workforce } \\
\text { median } \\
\text { n Ginarte } \\
\text { Law is an } \\
\text { xpropriation } \\
\text { intry Risk } \\
\text { s affiliate } \\
\text { e net } \\
\text { ent standard }\end{array}$ \\
\hline
\end{tabular}


Table IV

Parent Ownership Decisions

\begin{tabular}{|c|c|c|c|c|c|c|}
\hline \multirow[t]{2}{*}{ Dependent Variable: } & \multicolumn{6}{|c|}{ Share of Affiliate Equity Owned by Parent } \\
\hline & (1) & (2) & (3) & (4) & (5) & (6) \\
\hline Creditor Rights & $\begin{array}{r}-0.0091 \\
(0.0028)\end{array}$ & $\begin{array}{r}-0.0101 \\
(0.0035)\end{array}$ & $\begin{array}{r}-0.0010 \\
(0.0031)\end{array}$ & & & \\
\hline $\begin{array}{l}\text { Creditor Rights*Log of Parent } \\
\text { R\&D }\end{array}$ & & & $\begin{array}{r}-0.0010 \\
(0.0003)\end{array}$ & & & \\
\hline Private Credit & & & & $\begin{array}{r}-0.0506 \\
(0.0135)\end{array}$ & $\begin{array}{r}-0.0481 \\
(0.0174)\end{array}$ & $\begin{array}{r}0.0078 \\
(0.0144)\end{array}$ \\
\hline $\begin{array}{l}\text { Private Credit*Log of Parent } \\
\text { R\&D }\end{array}$ & & & & & & $\begin{array}{r}-0.0057 \\
(0.0009)\end{array}$ \\
\hline FDI Ownership Restrictions & $\begin{array}{r}-0.0728 \\
(0.0126)\end{array}$ & $\begin{array}{r}-0.0637 \\
(0.0133)\end{array}$ & $\begin{array}{r}-0.0611 \\
(0.0134)\end{array}$ & $\begin{array}{r}-0.0622 \\
(0.0117)\end{array}$ & $\begin{array}{r}-0.0560 \\
(0.0122)\end{array}$ & $\begin{array}{r}-0.0529 \\
(0.0122)\end{array}$ \\
\hline Workforce Schooling & $\begin{array}{r}0.0005 \\
(0.0024)\end{array}$ & $\begin{array}{r}-0.0049 \\
(0.0024)\end{array}$ & $\begin{array}{r}-0.0044 \\
(0.0025)\end{array}$ & $\begin{array}{r}0.0007 \\
(0.0026)\end{array}$ & $\begin{array}{r}-0.0030 \\
(0.0026)\end{array}$ & $\begin{array}{r}-0.0026 \\
(0.0026)\end{array}$ \\
\hline Log of GDP & $\begin{array}{r}-0.0157 \\
(0.0037)\end{array}$ & $\begin{array}{r}-0.0116 \\
(0.0046)\end{array}$ & $\begin{array}{r}-0.0116 \\
(0.0045)\end{array}$ & $\begin{array}{r}-0.0110 \\
(0.0035)\end{array}$ & $\begin{array}{r}-0.0079 \\
(0.0046)\end{array}$ & $\begin{array}{r}-0.0079 \\
(0.0046)\end{array}$ \\
\hline Log of GDP per Capita & $\begin{array}{r}0.0309 \\
(0.0064)\end{array}$ & $\begin{array}{r}0.0358 \\
(0.0132)\end{array}$ & $\begin{array}{r}0.0363 \\
(0.0132)\end{array}$ & $\begin{array}{r}0.0381 \\
(0.0078)\end{array}$ & $\begin{array}{r}0.0402 \\
(0.0143)\end{array}$ & $\begin{array}{r}0.0416 \\
(0.0144)\end{array}$ \\
\hline Corporate Tax Rate & $\begin{array}{r}-0.2633 \\
(0.0638)\end{array}$ & $\begin{array}{r}-0.3456 \\
(0.0712)\end{array}$ & $\begin{array}{r}-0.3391 \\
(0.0700)\end{array}$ & $\begin{array}{r}-0.2778 \\
(0.0584)\end{array}$ & $\begin{array}{r}-0.3249 \\
(0.0582)\end{array}$ & $\begin{array}{r}-0.3179 \\
(0.0564)\end{array}$ \\
\hline Patent Protections & & $\begin{array}{r}-0.0142 \\
(0.0073)\end{array}$ & $\begin{array}{r}-0.0137 \\
(0.0072)\end{array}$ & & $\begin{array}{r}-0.0127 \\
(0.0078)\end{array}$ & $\begin{array}{r}-0.0122 \\
(0.0077)\end{array}$ \\
\hline Property Rights & & $\begin{array}{r}0.0055 \\
(0.0072)\end{array}$ & $\begin{array}{r}0.0044 \\
(0.0075)\end{array}$ & & $\begin{array}{r}0.0000 \\
(0.0071)\end{array}$ & $\begin{array}{r}-0.0014 \\
(0.0072)\end{array}$ \\
\hline Rule of Law & & $\begin{array}{r}0.0005 \\
(0.0061)\end{array}$ & $\begin{array}{r}0.0012 \\
(0.0061)\end{array}$ & & $\begin{array}{r}0.0009 \\
(0.0061)\end{array}$ & $\begin{array}{r}0.0017 \\
(0.0060)\end{array}$ \\
\hline Risk of Expropriation & & $\begin{array}{r}0.0054 \\
(0.0068)\end{array}$ & $\begin{array}{r}0.0050 \\
(0.0068)\end{array}$ & & $\begin{array}{r}0.0069 \\
(0.0066)\end{array}$ & $\begin{array}{r}0.0059 \\
(0.0067)\end{array}$ \\
\hline Constant & $\begin{array}{r}1.1593 \\
(0.1006)\end{array}$ & $\begin{array}{r}1.0774 \\
(0.1147)\end{array}$ & $\begin{array}{r}1.0675 \\
(0.1121)\end{array}$ & $\begin{array}{r}0.9833 \\
(0.0947)\end{array}$ & $\begin{array}{r}0.9356 \\
(0.1055)\end{array}$ & $\begin{array}{r}0.9159 \\
(0.1018)\end{array}$ \\
\hline $\begin{array}{l}\text { Parent-Year Fixed Effects? } \\
\text { Affiliate Controls? }\end{array}$ & $\begin{array}{l}\mathrm{Y} \\
\mathrm{N}\end{array}$ & $\begin{array}{l}\mathrm{Y} \\
\mathrm{Y}\end{array}$ & $\begin{array}{l}\mathrm{Y} \\
\mathrm{Y}\end{array}$ & $\begin{array}{l}\mathrm{Y} \\
\mathrm{N}\end{array}$ & $\begin{array}{l}\mathrm{Y} \\
\mathrm{Y}\end{array}$ & $\begin{array}{l}\mathrm{Y} \\
\mathrm{Y}\end{array}$ \\
\hline $\begin{array}{l}\text { No. of Obs. } \\
\text { R-Squared }\end{array}$ & $\begin{array}{c}51,320 \\
0.3974\end{array}$ & $\begin{array}{c}41,436 \\
0.4250\end{array}$ & $\begin{array}{c}40,498 \\
0.4184\end{array}$ & $\begin{array}{c}48,422 \\
0.3998\end{array}$ & $\begin{array}{c}39,096 \\
0.4275\end{array}$ & $\begin{array}{c}38,198 \\
0.4217\end{array}$ \\
\hline $\begin{array}{l}\text { Notes: The dependent variable is the } \\
\text { rights developed in Djankov, McLies } \\
\text { private credit lent by deposit money b } \\
\text { measures of restrictions on foreign on } \\
\text { the average schooling years in the por } \\
\text { paid by affiliates in a particular count } \\
\text { Property Rights is an index of the stre } \\
\text { strength and impartiality of a country' } \\
\text { the risk of outright confiscation or for } \\
\text { values of this index reflect lower risks } \\
\text { specifications presented in columns } 2 \text {, } \\
\text { Net PPE/Assets is the ratio of affiliate } \\
\text { clustering at the countrv-vear level an a }\end{array}$ & $\begin{array}{l}\text { measured by } \\
\text { r. Patent Prot } \\
\text { pperty rights } \\
\text { gal system dr } \\
\text { alization of pr } \\
\text { ecification is } \\
6 \text { include the } \\
\text { rty plant and } \\
\text { entheses }\end{array}$ & $\begin{array}{l}\mathrm{z} \text { (2000) are } \\
\text { vided in Barr } \\
\text { ns is an index } \\
\text { from the } 199 \\
\text { from theInter } \\
\text { f affiliate sale } \\
\text { ment to affilise, al }\end{array}$ & $\begin{array}{l}\text { d Lee (2000). } \\
\text { le strength of } \\
\text { lex of Econom } \\
\text { nal Country } \\
\text { is also drawn } \\
\text { at includes pa } \\
\text { log of affilia } \\
\text { ssets. Heteros }\end{array}$ & $\begin{array}{l}\text { to } 5 \text { and one } \\
\text { porate Tax R } \\
\text { tt rights prov } \\
\text { reedom. Ru } \\
\text { Guide. Risk } \\
\text { the Internat } \\
\text { year fixed ef } \\
\text { nployment, a } \\
\text { sticity consi }\end{array}$ & $\begin{array}{l}\text { of the strengt } \\
\text { ns. Private c } \\
\text { ummy equal } \\
\text { wise. Workf } \\
\text { the median } \\
\text { in Ginarte an } \\
\text { Law is an ass } \\
\text { xpropriation i } \\
\text { Country Risk } \\
\text { As affiliate } \\
\text { filiate net PP } \\
\text { standard erro }\end{array}$ & $\begin{array}{l}\text { creditor } \\
\text { is the ratio of } \\
\text { ro if two } \\
\text { Schooling is } \\
\text { ive tax rate } \\
\mathrm{k} \text { (1997). } \\
\text { ent of the } \\
\text { index of } \\
\text { de; higher } \\
\text { ols, the } \\
\text { ets. Affiliate } \\
\text { th correct for }\end{array}$ \\
\hline
\end{tabular}


Table V

Liberalizations and Multinational Firm Scale

\begin{tabular}{|c|c|c|c|c|}
\hline \multirow[t]{2}{*}{ Dependent Variable: } & \multicolumn{2}{|c|}{ Log of Affiliate Sales } & \multicolumn{2}{|c|}{$\begin{array}{c}\text { Log of Aggregate Affiliate } \\
\text { Sales } \\
\end{array}$} \\
\hline & (1) & $(2)$ & (3) & (4) \\
\hline Post Liberalization Dummy & $\begin{array}{r}0.0016 \\
(0.0684)\end{array}$ & $\begin{array}{r}-0.0073 \\
(0.0712)\end{array}$ & $\begin{array}{r}-0.0633 \\
(0.1230)\end{array}$ & $\begin{array}{l}-0.1049 \\
(0.1262)\end{array}$ \\
\hline $\begin{array}{l}\text { Post Liberalization Dummy * Low } \\
\text { Creditor Rights Dummy }\end{array}$ & $\begin{array}{r}0.3011 \\
(0.0827)\end{array}$ & & $\begin{array}{r}0.3682 \\
(0.1552)\end{array}$ & \\
\hline $\begin{array}{l}\text { Post Liberalization Dummy * Low } \\
\text { Private Credit Dummy }\end{array}$ & & $\begin{array}{r}0.2947 \\
(0.0899)\end{array}$ & & $\begin{array}{r}0.3812 \\
(0.1769)\end{array}$ \\
\hline Log of GDP & $\begin{array}{r}0.3886 \\
(0.3888)\end{array}$ & $\begin{array}{r}0.3409 \\
(0.3960)\end{array}$ & $\begin{array}{r}-0.0786 \\
(0.7833)\end{array}$ & $\begin{array}{r}-0.1351 \\
(0.7040)\end{array}$ \\
\hline Log of GDP per Capita & $\begin{array}{r}1.3675 \\
(0.3720)\end{array}$ & $\begin{array}{r}1.4488 \\
(0.3867)\end{array}$ & $\begin{array}{r}2.6620 \\
(0.5425)\end{array}$ & $\begin{array}{r}2.8376 \\
(0.6192)\end{array}$ \\
\hline Constant & $\begin{array}{l}-13.5818 \\
(9.2414)\end{array}$ & $\begin{array}{r}-13.0613 \\
(9.2484)\end{array}$ & $\begin{array}{r}-4.7847 \\
(22.1876)\end{array}$ & $\begin{array}{r}-4.9033 \\
(20.0397)\end{array}$ \\
\hline $\begin{array}{l}\text { Affiliate and Year Fixed Effects? } \\
\text { Country and Year Fixed Effects? }\end{array}$ & $\begin{array}{l}\mathrm{Y} \\
\mathrm{N}\end{array}$ & $\begin{array}{l}\mathrm{Y} \\
\mathrm{N}\end{array}$ & $\begin{array}{l}\mathrm{N} \\
\mathrm{Y}\end{array}$ & $\begin{array}{l}\mathrm{N} \\
\mathrm{Y}\end{array}$ \\
\hline $\begin{array}{l}\text { No. of Obs. } \\
\text { R-Squared }\end{array}$ & $\begin{array}{r}180,796 \\
0.8035\end{array}$ & $\begin{array}{r}181,103 \\
0.8040\end{array}$ & $\begin{array}{c}827 \\
0.9243\end{array}$ & $\begin{array}{r}845 \\
0.9251\end{array}$ \\
\hline $\begin{array}{l}\text { Notes: The dependent variable in the first tw } \\
\text { the log of affiliate sales aggregated across af } \\
\text { The Post Liberalization Dummy is equal to } \\
\text { years following liberalization of foreign owr } \\
\text { related to countries with below median level } \\
\text { and zero otherwise. The Low Private Credit } \\
\text { private credit among liberalizing countries } n \\
\text { of the strength of creditor rights developed i } \\
\text { by deposit money banks to GDP, as provide } \\
\text { affiliate and year fixed effects, and the last } \\
\text { consistent standard errors that correct for cll }\end{array}$ & $\begin{array}{l}\text { e log of affiliat } \\
\text { icular country. } \\
\text { en countries th } \\
\text { ons. The Low } \\
\text { hts among libe } \\
\text { al to one for ob } \\
\text { year prior to lib } \\
\text { Liesh, and Shlei } \\
\text { (1999). The fi } \\
\text { cifications that }\end{array}$ & $\begin{array}{l}\text {, and the dep } \\
\text { lata are annuc } \\
\text { ralize their ov } \\
\text { or Rights Dur } \\
\text { g countries m } \\
\text { ions related t } \\
\text { ation and zerc } \\
007) \text {. Private } \\
\text { specificatio } \\
\text { le country an }\end{array}$ & $\begin{array}{l}\text { t variable in the la } \\
\text { a covering the } 198 \\
\text { hip restrictions in } \\
\text { is equal to one for } \\
\text { red in the year prio } \\
\text { ntries with below I } \\
\text { rwise. Creditor R } \\
\text { it is the ratio of pri } \\
\text { OLS specificatior } \\
r \text { fixed effects. He }\end{array}$ & $\begin{array}{l}\text { o columns is } \\
99 \text { period. } \\
\text { ear of and } \\
\text { rvations } \\
\text { iberalization } \\
\text { an levels of } \\
\text { is an index } \\
\text { credit lent } \\
\text { t include } \\
\text { kedasticity }\end{array}$ \\
\hline
\end{tabular}

